\title{
Persistence and turnover in desert plant communities during a 37-yr period of land use and climate change
}

\author{
Scott R. Abella iD $, 1,4$ Ross J. Guida, ${ }^{2}$ Chris L. Roberts, ${ }^{3}$ Carrie M. Norman, ${ }^{3}$ and James S. Holland ${ }^{3}$ \\ ${ }^{1}$ School of Life Sciences, University of Nevada Las Vegas, Las Vegas, Nevada 89154-4004 USA \\ ${ }^{2}$ Department of Geography and Geology, Sam Houston State University, Huntsville, Texas 77431 USA \\ ${ }^{3}$ National Park Service, Lake Mead National Recreation Area, 601 Nevada Way, Boulder City, Nevada 89005 USA
}

Citation: Abella, S. R., R. J. Guida, C. L. Roberts, C. M. Norman, and J. S. Holland. 2019. Persistence and turnover in desert plant communities during a 37-yr period of land use and climate change. Ecological Monographs 00(00):e01390. 10.1002/ecm.1390

Abstract. Understanding long-term changes in ecological communities during global change is a priority for 21 st-century ecology. Deserts, already at climatic extremes, are of unique interest because they are projected to be ecosystems most responsive to global change. Within a $500-\mathrm{km}^{2}$ landscape in the Mojave Desert, USA, we measured perennial plant communities at 100 sites three times $(1979,2008$, and 2016) during $37 \mathrm{yr}$ to evaluate six hypotheses of community change. These hypotheses encompassed shifts in community measures (e.g., diversity, cover) and species elevational distributions, biotic homogenization, disproportionately large change at the highest elevations, relationships between turnover and species' responses to disturbance and drought, and that environmental refugia (e.g., moist topographic positions) would receive species during climatic warming and drying. Most community measures changed temporally, such as species density (species $/ 600 \mathrm{~m}^{2}$ ) increasing $23 \%$ and plant cover doubling between 1979 and 2016. There was no increase in nonnative species and minimal evidence for biotic homogenization. High-elevation communities did not display greater change than lowelevation communities. Moreover, environmental refugia factored little in species shifts. While species distributional changes were unrelated to affinity for disturbance, the six most persistent species (persisting on $>80 \%$ of sites) were long-lived shrubs not associated with disturbance. Overall, seemingly paradoxically, climatic warming and drying was associated with increasing plant abundance. Comparing the 1970s to 2007-2016, precipitation in the study area declined $16 \%$ from 17 to $14 \mathrm{~cm} / \mathrm{yr}$ and average daily minimum temperature rose $13 \%\left(1.2^{\circ} \mathrm{C}\right)$. The current climate with fewer freezes, together with reduced grazing, could be among the most optimal for desert perennials in the past century, although potential response lags to continuing warming and drying are uncertain. This study of long-term elevational shifts in communities during global change is among few in deserts, and the average upward elevational shift of $6 \mathrm{~m} /$ decade for species in our study is within the range reported for temperate biomes. However, the $41 \%$ of species moving downslope is unusually high. We propose that dynamics within desert perennial communities follow a core-transient species model where a site's species are either highly persistent or transient in approximately equal proportions.

Key words: biotic homogenization; core-transient model; elevation; Mojave Desert; range shift; refugia; resistance; species distribution; stability.

\section{INTRODUCTION}

Understanding current and potential future ecological responses to global change drivers such as climate, biological invasions, and land use is one of the greatest challenges facing ecologists in the 21st century. Generalizations have been elusive for ecological responses to global change, in part because long-term studies are uncommon, and a diversity of complex, often unexpected responses have occurred. As examples, seeming paradoxically, warming and drying in the Sonoran

Manuscript received 14 July 2018; revised 25 April 2019; accepted 9 July 2019. Corresponding Editor: Sasha C. Reed.

[4E-mail: scott.abella@unlv.edu
Desert over $25 \mathrm{yr}$ favored cold-tolerant plants, as they benefited from a shift in seasonal precipitation from fall to winter (Kimball et al. 2010). Contrasting with theoretical predictions of increased plant growth expected from relationships between $\mathrm{CO}_{2}$ and plant productivity, rising atmospheric $\mathrm{CO}_{2}$ concentrations did not increase biomass or cover of desert perennials during a 10-yr experiment (Newingham et al. 2014). Similarly, while it may seem logical to anticipate that species shift upward in elevation within landscapes during climatic warming, $25 \%$ of species have shifted downward (Lenoir et al. 2010, Chen et al. 2011).

Adding to the complexity is that multiple global change drivers interact concurrently in some landscapes (McCarty 2001). Drivers such as land use (e.g., livestock 
grazing), fire regimes, and biological invasions often produce complex, interactive effects with climate (Groffman et al. 2012). On a Mediterranean landscape in France, for example, fires affected bird distributions in a manner similar to the climatic effects of moving $600 \mathrm{~km}$ southward or increasing average temperature by $2-5^{\circ} \mathrm{C}(\mathrm{Cla}-$ vero et al. 2011). In addition to fire, grazing by livestock, the most extensive human land use covering $25 \%$ of terrestrial Earth, has influenced vegetation structure and can interact with climate change (Asner et al. 2004).

By already occupying areas of climatic extremes, deserts are predicted to be among the most responsive ecosystems to global change (McCluney et al. 2012, Munson et al. 2012). Despite occupying a third of Earth's land area, knowledge of long-term ecological change in deserts is under-represented compared to moister biomes (Tielbörger and Salguero-Gómez 2014). Here, using a Mojave Desert landscape in the southwestern United States as a model system, we evaluated six hypotheses of long-term change in desert perennial vegetation over four decades across broad environmental gradients. We examined changes in perennial plant species density, abundance, and composition, nonnative species, biotic homogenization, shifts in species distributions with elevation, and relationships of species traits with distributional shifts (Table 1).

First, we hypothesized that there would be no net change in the community measures of perennial species density (species/600 $\mathrm{m}^{2}$ ), plant density (individuals/ha), cover, and species compositional turnover through time and across elevations. We based this hypothesis on the observation that all three possible responses (no change, increase, decrease) are represented in the literature, with little consensus on where and when particular responses can be reliably predicted during global change. For example, plant species density remained unchanged

TABLE 1. Hypotheses of long-term change in perennial vegetation evaluated in the Newberry Mountains, Mojave Desert, Nevada, USA.

\begin{tabular}{lc}
\hline \hline Hypothesis & Evidence \\
\hline 1) There is no change in species density, plant & reject \\
density, cover, and species composition among & \\
years and community types. & mixed \\
2) Biotic homogenization will occur over time & \\
through declining species and community & \\
diversity. & mixed \\
3) The upper, lower, and average elevations of & \\
species distributions will shift upward and ranges & \\
will expand. & reject \\
4) The highest elevations will display the greatest \\
change in species distribution, plant density, \\
cover, and composition. \\
5) Species will shift to topographically cooler and \\
moister sites, such as canyons and north-facing \\
slopes. \\
$\begin{array}{l}\text { 6) Species distributional changes will be associated } \\
\text { with disturbance and drought tolerance and } \\
\text { biogeographical limits. }\end{array}$ \\
\hline
\end{tabular}

during $85 \mathrm{yr}$ of warming in arctic habitats in Norway (Kapfer and Grytnes 2017), increased during $45 \mathrm{yr}$ in the cold Great Basin Desert in the United States (Anderson and Inouye 2001), and declined over $55 \mathrm{yr}$ in deciduous forests in Belgium (Verstraeten et al. 2013). Similar to these correlative field results, experiments have revealed that global change factors inconsistently influence community measures such as plant diversity and that different factors applied in combination can negate each other (Cahill et al. 2013).

Second, we hypothesized that biotic homogenization will occur over time, as evidenced by declining species diversity and community heterogeneity. Biotic homogenization is the impoverishment of local species diversity through losing specialist species or replacing them with generalists, or the loss of unique community types (Clavel et al. 2011). Olden and Poff (2003) presented a conceptual model depicting 14 scenarios by which biotic homogenization could occur, ranging from invasion across communities to homogenize them, local extinctions such as loss of one species originally not shared by communities, to both invasion and extinction (e.g., loss of species originally differentiating communities and replacement or no replacement of the specialists with generalists). Many ecosystems have recently experienced biotic homogenization, such as forests of Germany during $50 \mathrm{yr}$ of nutrient enrichment (Heinrichs and Schmidt 2017), heaths in Scotland under $50 \mathrm{yr}$ of warming and acidifying conditions (Ross et al. 2012), and prairies in Argentina under $35 \mathrm{yr}$ of grazing (Puhl et al. 2014).

Third, we hypothesized that the upper, lower, and average elevations of species distributions will shift upward. Many types of range shifts with elevation are possible under global change. Most studies report upward elevational shifts, including expectations for local extinctions of species inhabiting the highest elevations (Parmesan and Hanley 2015). In a global all-taxa meta-analysis, species shifted their median elevations upward by $11 \mathrm{~m} /$ decade during the 1900s and 2000s (Chen et al. 2011). While some studies in temperate biomes reported that certain species moved downslope or remained in place (Lenoir et al. 2010), we anticipated that if desert communities are particularly sensitive to warming and drying, desert species should shift upward to track cooler and moister climates, as previously observed for three high-elevation Mojave Desert species (Guida et al. 2014).

Fourth, we hypothesized that plant communities will change the most at the highest elevations. This expectation stems from both theory and empirical data. Theoretically, the elevation-for-latitude temperature model $\left(1^{\circ} \mathrm{C}\right.$ decrease in temperature per $167 \mathrm{~m}$ increase in elevation or $145 \mathrm{~km}$ of latitude) forecasts that communities at the highest elevations should respond the most to warming through several mechanisms (Jump et al. 2009). To colonize mountaintops and thus increase community turnover, species need only disperse short distances along elevation gradients, compared to long 
distances to track climate along latitudinal gradients. In terms of potential for latitudinal migration to maintain species populations, the greater area and connectivity of lowlands (compared to small and isolated mountaintops with imminent upper elevation limits) theoretically translates to greater area available for migration of lowland compared to highland species (Jump et al. 2009). Additionally, owing to the small habitat area of high-elevation species and therefore likely smaller population sizes, capacity for adaptation for in situ persistence could be lower for high-elevation than for lowland species with large populations (Parmesan 2006). Empirical data from forests in France support the theoretical expectations. High-elevation forests responded to $50 \%$ of the $1.1^{\circ} \mathrm{C}$ warming over $44 \mathrm{yr}$ (1965-2008) through shifts in species composition, compared to lowlands responding to only $2 \%$ of the warming (Bertrand et al. 2011).

Fifth, we tested the environmental refugia hypothesis, whereby species distributions shift to cooler and moister sites under a warming climate. The ability of species to exploit environmental refugia to persist within landscapes under emerging climates hinges on several factors, such as habitat suitability in potential refugia, the ability to disperse to them, and availability of open niches (McLaughlin et al. 2017). For example, northfacing slopes or steep canyons could continue meeting hydrologic requirements for species under climatic warming and drying, but perhaps not provide sufficient sunlight. Given our study area's dissected topography, creating a diversity of potential refugia and open vegetation physiognomy, we anticipated that refugia would be linked with species distributional changes.

Sixth, we tested the expectation that species displaying the least distributional change are the most drought tolerant, not near their biogeographic range limits, and are the longest lived and least associated with disturbance. Among biomes, there is mixed evidence that species traits relate to long-term distributional shifts during global change (Parmesan and Hanley 2015). Along with challenges in measuring traits, this inconsistency could relate to whether species are "drivers" or "passengers" during global change, or if different traits negate each other in changing environments (HilleRisLambers et al. 2010). Traits such as $\mathrm{N}$ fixation, growth form, and seasonal growth pattern were related to long-term species distributional changes in some studies (e.g., Leach and Givnish 1996, Laughlin et al. 2011, Munson et al. 2011), but traits were minimally or inconsistently related in others (e.g., Puhl et al. 2014, Ash et al. 2017).

\section{Methods}

\section{Study area}

The $500-\mathrm{km}^{2}$ study area, in the eastern Mojave Desert near the transition to the south with the Sonoran Desert, included a desert mountain range (Newberry
Mountains) and surrounding lowlands, in southern Nevada, USA (Fig. 1). Managed by the National Park Service (Lake Mead National Recreation Area) and Bureau of Land Management (Southern Nevada District), much of the study area is within the Piute-Eldorado Valley Area of Critical Environmental Concern and Bridge Canyon and Spirit Mountain Wilderness areas. Recent disturbance by humans has been minimal. Past anthropogenic disturbance was primarily via grazing by livestock (cattle and sheep) and feral burros (Equus asi$n u s$ ). Early livestock grazing may have begun by the mid- to late 1800 s through nearby ranching operations and mineral prospecting that utilized burros (National Park Service 1994). Documented livestock grazing occurred from 1924 through the 1970s, preceding initiation of our study in 1979. During 1975-1979, the study area's grazing allotment had an authorized use of 3,711 animal unit months/year, corresponding with a density of 1 livestock animal $/ \mathrm{km}^{2}$ (Bureau of Land Management 1982). The allotment was decommissioned by 1994 . Population sizes of feral burros are unknown, but they were documented as present in the Newberry Mountains in 1957 (McKnight 1958). Burros may have persisted in the area through the 1980s until management efforts sought to remove remaining individuals by 1994 (National Park Service 1994). The main native large herbivores in the study area are desert bighorn sheep (Ovis canadensis nelsoni), with a density of 1 individual $/ \mathrm{km}^{2}$ in suitable mountain habitat (Bureau of Land Management 1982).

The study area encompassed a broad biophysical gradient. Elevations ranged from $183 \mathrm{~m}$ near the Colorado River to $1,719 \mathrm{~m}$ at the summit of Spirit Mountain. Long-term climate (1914 through 2016) at a nearby weather station averaged $20 \mathrm{~cm} / \mathrm{yr}$ of precipitation, a January daily low temperature of $2^{\circ} \mathrm{C}$, and a July daily high temperature of $36^{\circ} \mathrm{C}$ (Searchlight, Nevada, $17 \mathrm{~km}$ northwest of the study area and $1,079 \mathrm{~m}$ in elevation; Western Regional Climate Center, Reno, Nevada, USA). Slope gradients ranged from $5^{\circ}$ to $40^{\circ}$. Granite is the primary rock type of the Newberry Mountains, with some diorite and gneiss (Walker et al. 2007). Soils are coarse-textured and mostly classified as Typic and Lithic Torriorthents and Ustic Haplargids (Lato 2006). Major vegetation types include shrublands dominated by Encelia farinosa or Larrea tridentata on the warmest and low- to mid-elevation sites, and mixed-species shrublands that include Juniperus californica and Pinus monophylla at the highest elevations (Fig. 2).

\section{Data collection}

In 1979,111 transects, each $6 \times 100 \mathrm{~m}\left(600 \mathrm{~m}^{2}\right)$, were established across the study area (Fig. 1). Transects were placed along three stratified, randomly selected, eastwest zones (by dividing the study area into thirds) and three north-south zones. Within these zones, transects were placed across the landscape using a systematic, stratified design to encompass elevations and vegetation 


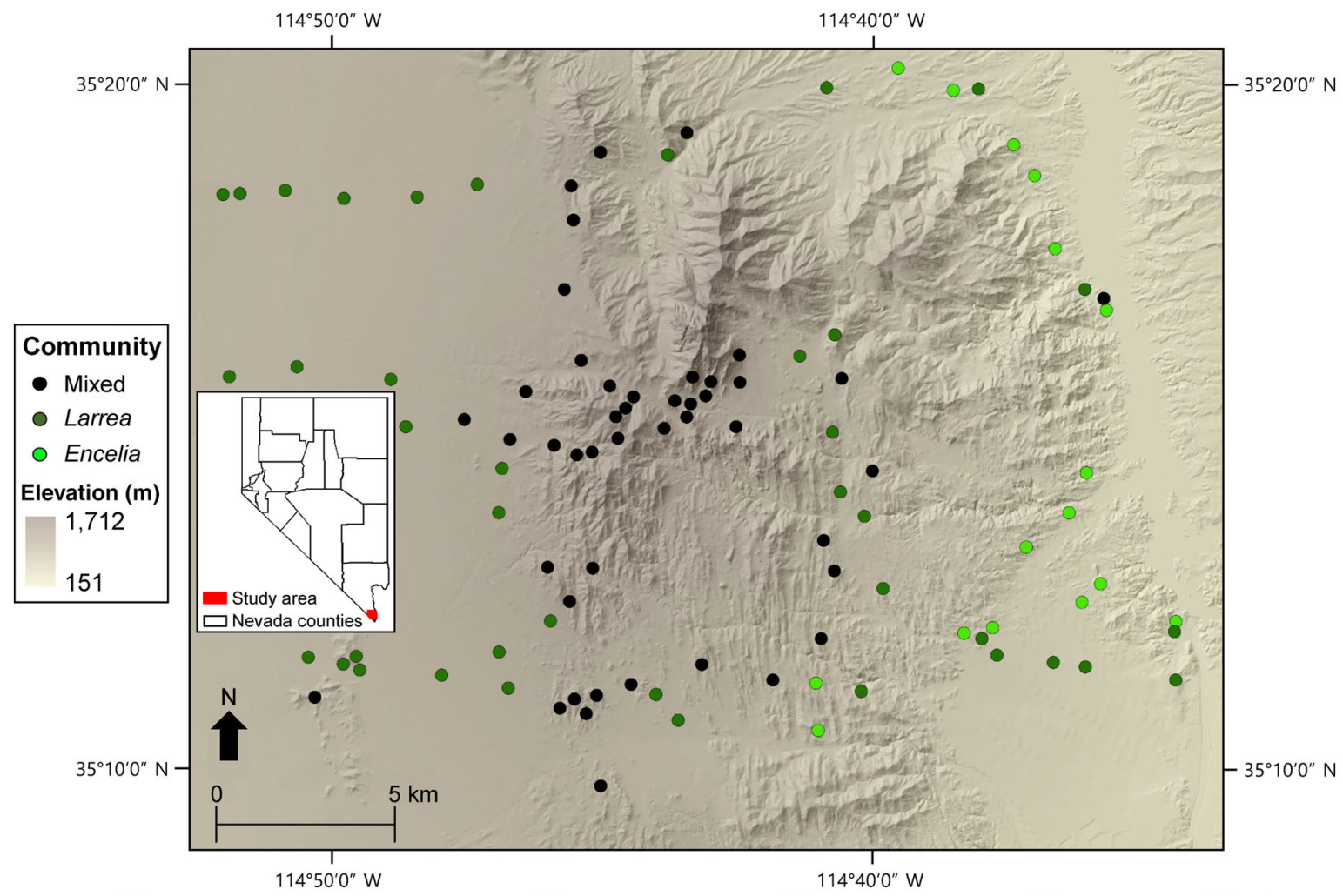

FIG. 1. Distribution of 100 transects where perennial vegetation was measured in 1979, 2008, and 2016 in the Newberry Mountains, Mojave Desert, Nevada, USA. Transects are classified by community type corresponding with warm, low-elevation sites (Encelia), low-mid elevations (Larrea), and mid-high elevations (mixed shrub).

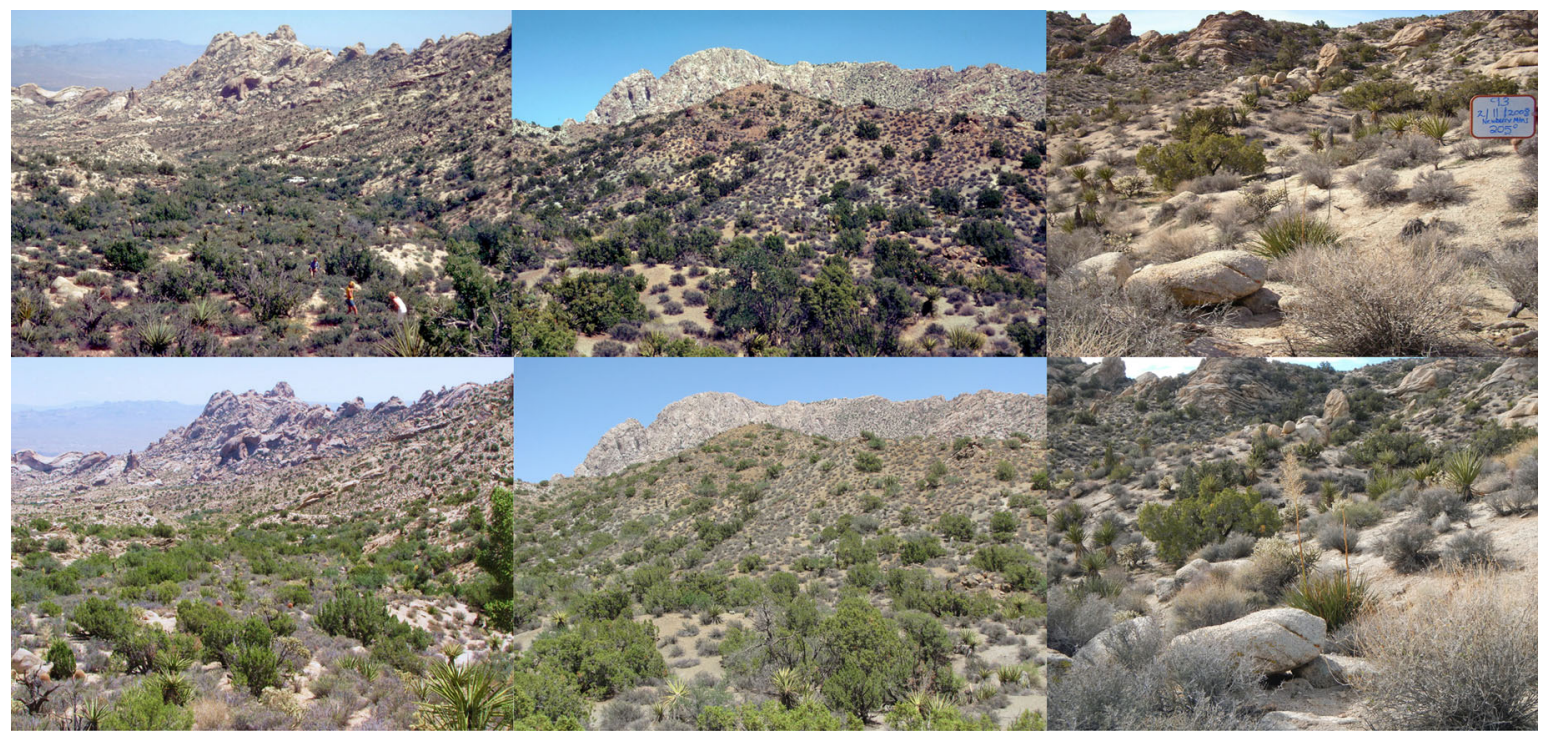

FIG. 2. Repeat photos of vegetation in the Newberry Mountains, Mojave Desert, Nevada, USA. Left and middle photo pairs: 1979 (top) and 2008 (bottom). Right photo pair: 2008 (top) and 2016 (bottom). Dominant species in the views include the small tree Juniperus californica, which increased in cover; Yucca schidigera, which generally persisted and grew taller; the low grayish shrub Coleogyne ramosissima, which persisted and in some cases had individuals that appeared to change little in size (e.g., middle photo pair in the open area of the left foreground); and Encelia farinosa, with a close-up view in the bottom right of the right photo pair. Photos by J. S. Holland (1979), C. L. Roberts (2008), and S. R. Abella (2016). 
types. Transects were spaced every $1 \mathrm{~km}$, or where a $>50$-m change in elevation occurred relative to a previous transect. In 2007-2008, we relocated transects (which were not permanently marked in 1979) using digitized locations of transects transcribed onto $7.5-\mathrm{min}$ topographic maps, detailed field notes recorded in 1979 (e.g., azimuths and distances to transects from geographic features), and assistance in the field from the original investigator (J. S. Holland) who established the study. We estimate that transects were typically relocated to within $10 \mathrm{~m}$ of their original location and always within the same vegetation type, and in some cases were nearly exact relocations. In 2007-2008, we recorded location using a global positioning system for all relocated transects. We used 100 of the original 111 transects, with 11 transects destroyed (via road building) or unable to be relocated and accessed, therefore excluded.

Perennial vegetation on transects was sampled three times in total during a 37-yr period, in 1979, 2007-2008, and 2015-2016, with the latter measurements completed 29 and $37 \mathrm{yr}$ after the initial 1979 measurement. Sampling was performed during the dormant season (autumn and winter) for each measurement period and extended into the next calendar year for 2007-2008 and 2015-2016 but still within the winter season (hereafter referred to as 1979, 2008, and 2016 as year of sample completion). Annual plants were not part of the study, which focused on perennial vegetation that is identifiable in autumn-winter in the Mojave Desert. Within entire $600-\mathrm{m}^{2}$ transects, the number of individuals of each perennial species was counted to measure plant density. Along the center of each transect, in 100 contiguous $1 \times 1 \mathrm{~m}$ quadrats, the areal cover of each species in each quadrat was categorized to the nearest $1 \%$ using a frame subdivided into 100 cells. Also using these quadrats, the frequency (number of $1-\mathrm{m}^{2}$ quadrats a species inhabited out of 100 quadrats) for each species on each transect was calculated. Nomenclature and categorization of species growth form (fern, cactus, grass, forb, shrub, or tree) and nativity to North America followed the PLANTS Database (Natural Resources Conservation Service, Greensboro, North Carolina, USA).

Continuity of investigators during the study facilitated consistency of methods across years, but despite this, two issues arose: consistently differentiating individuals for the clonal grass Pleuraphis rigida and distinguishing between Encelia spp. In general, Pleuraphis individuals were distinguished based on being spatially segregated (i.e., with an interspace $\geq 0.5 \mathrm{~m}$ between plants), but it is possible that density was under- or over-estimated certain years relative to other years. This possibility is difficult to evaluate, because measures independent of distinguishing individuals (cover and frequency) varied among years, implying that density could also have changed. We retained Pleuraphis density in the data set as measured each year. Encelia frutescens was differentiated from E. virginensis in 2008, but E. frutescens was not recorded in 1979 and 2016. It is unclear whether
E. frutescens was absent those years or simply not differentiated from E. virginensis, so we retained $E$. frutescens in the data set.

We obtained climate data for each transect interpolated from 800-m grids across the study area for 19702016 from the PRISM model (Daly et al. 2008). We further obtained instrumental climate records from the Searchlight, Nevada, weather station, $17 \mathrm{~km}$ northwest of the study area and at 1,079 $\mathrm{m}$ in elevation, comparable to the study area's mid-elevations (Western Regional Climate Center, Reno, Nevada, USA). As a long-term measure of aridity for comparison with our study period, we obtained the Palmer Drought Severity Index for southern Nevada from the National Oceanic and Atmospheric Administration (Washington, D.C., USA).

\section{Data analysis}

To identify initial communities present in 1979, we performed a cluster analysis (Euclidean distance with Ward's group-linkage method; total sum of squares $=21.8$, chaining $=2.2 \%$ ) using 1979 relative density in PC-ORD 7.07 (MjM Software Design, Gleneden Beach, Oregon, USA). Three major community types were identified along a primary elevation gradient: Encelia communities inhabiting the warmest and lowestelevation sites and dominated by Encelia farinosa; Larrea communities at the lower-middle elevations dominated by Larrea tridentata; and mixed shrublands on the highest-elevation sites (Table 2). We used these groupings to represent low-, mid-, and high-elevation communities for subsequent analyses. Using data for all years, we prepared six transect-year $\times$ species matrices using raw (plants/ha, percent cover, and percent frequency) and relative measures of plant abundance ( species $_{i} / \sum$ all species on a transect separately for each of the three raw measures). Next, we computed matrices of change for each measure by subtracting 1979 values from 2008 and 2016 values for each transect, and 2008 values from 2016 values. From these sets of matrices, we calculated Sørensen (separately for relative density, cover, and frequency) and Jaccard (presence-absence data) similarity within and among transects between years (1979:2008, 1979:2016, and 2008:2016) using PC-ORD. We then calculated three measures of species compositional turnover as the number of species that were lost, gained, or persisted from one measurement year to the next for each transect.

To evaluate our six hypotheses, we performed univariate and bivariate analyses in SAS 9.4 (SAS Institute, Cary, North Carolina, USA) and multivariate analyses in PC-ORD. To test Hypothesis 1 of no change in species density (species $/ 600 \mathrm{~m}^{2}$ ), plant density, and cover among years and community types across elevations, we used a two-factor, mixed-model, repeated-measures analysis of variance. The model included three levels of community type (Encelia, Larrea, and mixed), year (1979, 2008, and 2016), and their interaction, with transects as subjects. For models significant at $P<0.05$, 
TABLE 2. Summary of three community types across elevations used for analyzing $37 \mathrm{yr}$ of vegetation change in the Newberry Mountains, Mojave Desert, Nevada, USA.

\begin{tabular}{llll}
\hline \hline & \multicolumn{1}{c}{ Community } \\
\cline { 2 - 4 } & \multicolumn{1}{c}{ Encelia } & Larrea & Mixed \\
\hline Elevation category & low & medium & 45 \\
No. transects & 16 & 39 & $306-1,443$ \\
Elevation range $(\mathrm{m})$ & $230-729$ & $184-1,072$ & $1,026 \pm 32$ \\
Elevation $(\mathrm{m})$ & $382 \pm 37$ & $733 \pm 39$ & $15.3 \pm 0.1$ \\
Precipitation $(\mathrm{cm} / \mathrm{yr})$ & $13.4 \pm 0.2$ & $14.3 \pm 0.1$ & $24.8 \pm 0.2$ \\
High temperature $\left({ }^{\circ} \mathrm{C}\right)$ & $29.5 \pm 0.3$ & $26.9 \pm 0.3$ & $18 \pm 2$ \\
Slope gradient $\left({ }^{\circ}\right)$ & $22 \pm 3$ & $8 \pm 1$ & $1,390 \pm 51$ \\
Sunlight intensity $\left(\mathrm{Wh} \cdot \mathrm{m}^{-2} \cdot \mathrm{d}^{-1}\right)$ & $1,283 \pm 80$ & $1,411 \pm 20$ & $7.9 \pm 0.2$ \\
Sunlight duration $(\mathrm{h} / \mathrm{d})$ & $8.2 \pm 0.4$ & $8.9 \pm 0.1$ & Pinus monophylla, \\
Dominant plants & Encelia farinosa, & Ambrosia dumosa, & Eriogonum fasciculatum, \\
& Ambrosia dumosa, Larrea & Larrea tridentata, & Quercus turbinella, \\
& tridentata, Eriogonum & Bebbia juncea, Hymenoclea salsola, & Coleogyne ramosissima, \\
& fasciculatum, Krameria & Acamptopappus sphaerocephalus, & Juniperus californica, \\
& grayi, Viguiera parishii & Prunus fasciculata & Yucca schidigera \\
\hline
\end{tabular}

Notes: Precipitation and temperature are 2012-2016 averages for transects within communities. High temperatures are average monthly maximums. Sunlight intensity and duration are for the winter solstice. The dominant plants represent the six species within each community with the highest cover in 1979. Values are mean \pm SE.

least-squares means were separated using Tukey tests at the appropriate level of interaction or main effect. We used permutational multivariate analysis of variance (PERMANOVA; Anderson 2001) to compare species composition (based on relative plant density, relative cover, frequency, and presence/absence) among years, with each year having 100 transects. We then compared years within each separate community type to keep sample sizes equal, a conservative approach as PERMANOVA can be sensitive to unequal sample sizes. We used Sørensen distance for PERMANOVA of the quantitative compositional measures and Jaccard distance for presence-absence data. Transects served as a random variable for all analyses. For overall models significant at $P<0.05$, we made pairwise comparisons using Bonferroni-corrected randomization tests. The univariate compositional turnover measures (number of species persisting, gained, or lost on transects among years) were analyzed identically to the PERMANOVA implementation, except that Euclidean distance was used for the univariate permutational analysis of variance.

To assess evidence for biotic homogenization (Hypothesis 2), we calculated evenness and Shannon diversity using plant cover for each transect in PC-ORD. Next, we calculated within-community Sørensen similarity (based on relative cover) as the average of each pairwise similarity between transects within a community type and year. We calculated between-community Sørensen similarity by averaging species composition across all transects of a community each year and basing similarity on this averaged species composition. We calculated overall average similarities by averaging similarity across community types within years (within-community overall average similarity, $n=3$ for each year) and across each pairwise community comparison within years (between-community overall average similarity, $n=3$ for each year). We used the same two-factor, repeated-measures analysis of variance as for Hypothesis 1 to examine variation in evenness, Shannon diversity, and overall within-community similarity. To compare average between-community similarity among years, we used permutational analysis of variance (Anderson 2001) with community comparisons (e.g., Encelia $\times$ Larrea) within years serving as blocks.

For evaluating Hypothesis 3 that the upper, lower, and average elevations that species inhabit will increase, we examined 87 species that inhabited at least one transect every year (out of 159 total species). For each year, we computed the maximum, minimum, average, and range of elevations each species inhabited. We then calculated the average of each of these measures across the 87 species and compared each measure separately among years using a repeated measures analysis of variance. We used $G$-tests of goodness-of-fit to assess if the proportion of species differed that increased, decreased, or did not change in elevation between 1979 and 2016. We further correlated the maximum, minimum, average, and range of elevations each species inhabited in 1979 with those they inhabited in 2016.

For Hypothesis 4 (highest elevations will change the most), we used linear regression to relate elevation of transects with their species density, plant density, cover, and species turnover measures for each year. We then regressed elevation with the change in each measure through time (2008 minus 1979, 2016 minus 1979, and 2016 minus 2008).

To assess the environmental refugia hypothesis (Hypothesis 5), we used multiple regression to relate community turnover measures (number and proportion 
of species on each transect that persisted or were gained or lost) to environmental variables. We input nine environmental variables and screened them for inclusion in final multiple regression models using stepwise selection ( $P=0.15$ to enter or stay). We used the following environmental variables: elevation, slope aspect (in degrees), sunlight duration $(\mathrm{h} / \mathrm{d})$ and intensity $\left(\mathrm{Wh} \cdot \mathrm{m}^{-2} \cdot \mathrm{d}^{-1}\right)$ on the summer and winter solstice and average for the year, a topographic protection index calculated from 10-m digital elevation models with the solar analyst tool in ArcGIS 10.5 (ESRI, Redlands, California, USA), and soil available water capacity $(\mathrm{mm})$ estimated from the soil taxonomic unit each transect occupied (Lato 2006). To assess the potential importance of environmental variables for distributional changes of individual species, we examined the 46 species that were gained on at least three transects and lost on at least three transects between 1979 and 2016. For each of these species, we used $t$ tests to compare means of environmental variables from transects for when a species was gained or lost, separately for each species and with $P=0.05$ independently for each test.

To assess Hypothesis 6 (species elevational shifts are related to species' disturbance and drought tolerance and biogeographical range), we first used bivariate correlation to relate drought tolerance and a disturbance-affinity index with changes (2016 minus 1979) in the maximum, minimum, average, and range of elevations species inhabited. We used a drought tolerance index for the Mojave Desert and input as percent survival, available for 22 of our study's species (Schultz and Ostler 1995). The disturbance-affinity index, expressed as the ratio of disturbed: undisturbed area abundance for species, was synthesized from 47 studies in the Mojave and Sonoran Desert and available for 37 species in our study (Abella 2010). In general, long-lived species (centuries) in these deserts have affinity for undisturbed areas and low indices, while shorter-lived species (decades) are associated with disturbed areas and have high indices (Goldberg and Turner 1986, Bowers et al. 1995, Abella 2010). From Holland (1982) and herbarium records (Southwest Environmental Information Network, Arizona State University, Tempe, Arizona, USA), we identified 19 species in our study that were at their geographic range limit. These were species associated with the Sonoran Desert to the south and west, and lacked occurrences directly north or east of our study area. High mountains to the north and east are in the cold Great Basin Desert and Colorado Plateau. For the 19 range-limit species, we calculated changes between years in the maximum, minimum, average, and range of elevations inhabited. We then used a $2 \times 2 G$ test of independence to assess if the proportion of species increasing or decreasing their average elevational distribution between 1979 and 2016 differed between range-limit and non-range-limit species. We did not include a "no change" category because none of the 74 non-limit species present in both years and included in the analysis displayed no change in average elevation (i.e., all could be classified as increasing or decreasing) and only one of the range-limit species displayed no change.

\section{RESUlts}

\section{Climatic changes}

The 37-year study period encompassed several major climatic events plus general drying and warming (Fig. 3). A wet period preceding the 1979 inventory continued through the 1980s until a brief, but severe, drought occurred from 1989 to 1991. After a mid-1990s wet period, especially dry conditions generally prevailed after 1998, with the exception of the winter of 2004 2005, which produced the wettest conditions since 1940 and the second wettest since 1895 . Below-freezing January daily lows became less common. They occurred every six years on average between 1914 and 1978, but in only one year (2007) during the 37-yr study period since 1979. On average across the study area, interpolated climate data revealed that, from 1970 to 1979 compared with $2007-2016$, mean temperatures rose $13 \%\left(1.6^{\circ} \mathrm{C}\right)$ for the daily minimum, $3 \%\left(0.7^{\circ} \mathrm{C}\right)$ for the daily maximum, and $6 \%\left(1.2^{\circ} \mathrm{C}\right)$ for the daily average. Precipitation decreased $16 \%$ from 17 to $14 \mathrm{~cm} / \mathrm{yr}$.

\section{Overall community characteristics}

In total for the 100 transects, we recorded 105 perennial species in 1979, 132 in 2008, and 109 in 2016, with 159 species across all years. We inventoried 41,856 individual plants in $1979,36,301$ in 2008 , and 47,198 in 2016. Shrubs dominated all community types and years, with forbs, grasses, cacti, or trees secondarily prominent in some communities (Appendix S1: Table S1). All of the species detected during the study were native, except for one, Tamarix ramosissima. This species inhabited $2 \%$ of transects in 1979 and was absent in 2008 and 2016.

\section{Community measures among years and elevation (Hypothesis 1)}

We rejected the hypothesis of no change in community measures, as all 10 measures varied significantly among years (Table 3). Species density/600 $\mathrm{m}^{2}$ increased by an average of $23 \%$ between 1979 and 2016 among transects and increased the most at low and high elevations (Fig. 4). Increasing species density at the elevation extremes resulted from increases across all plant growth forms. Plant density and cover were highest in the highelevation mixed community, but cover increased significantly across all communities between 1979 and 2016 .

Species composition for all measures (relative density, cover, frequency, and presence/absence) differed among years overall and within community types (Table 3 ). However, one-half or more of the species composition on transects was stable among years. For example, average similarity between 1979 and 2008 for composition 


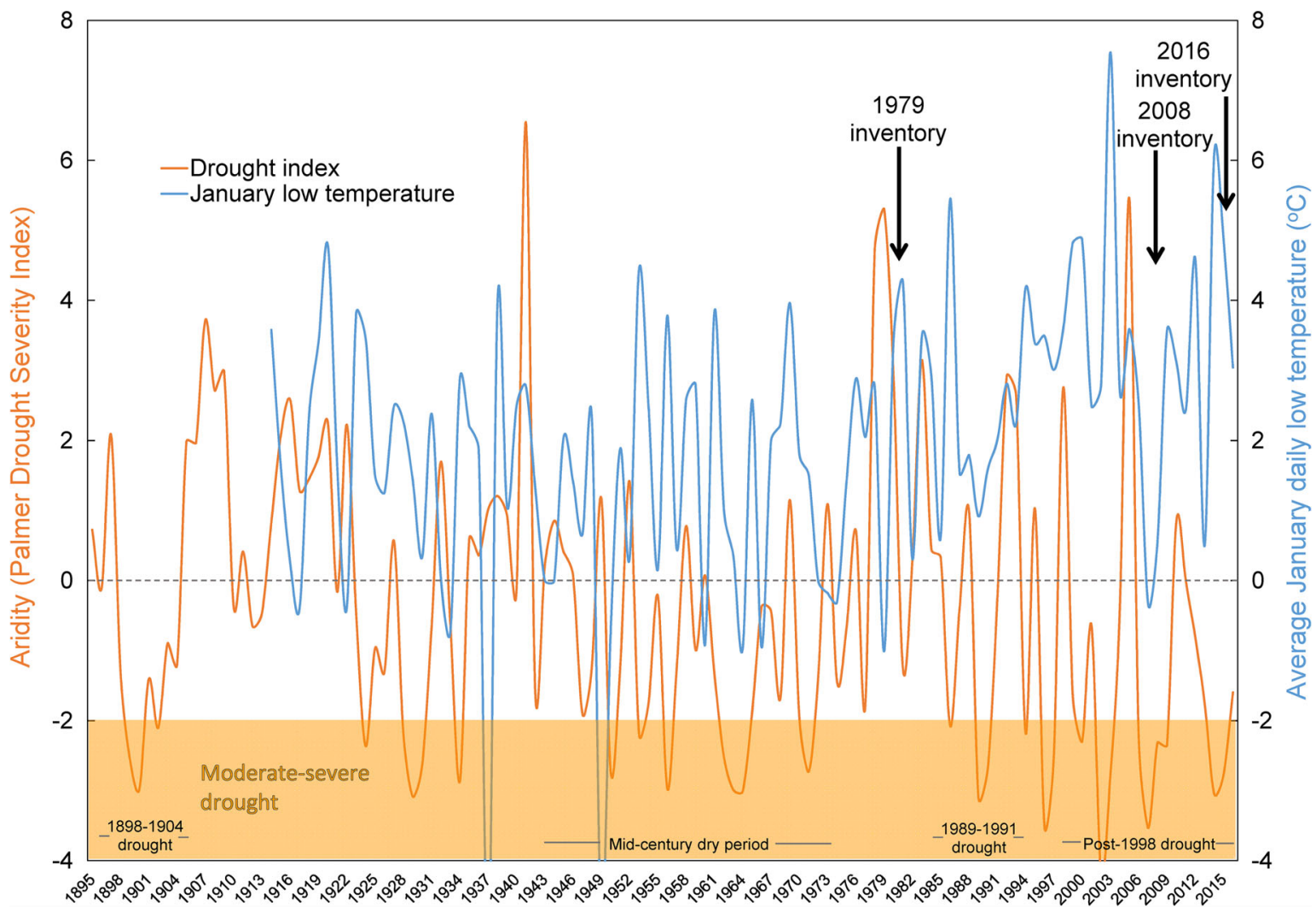

FIG. 3. Long-term climate in southern Nevada, USA, in relation to a 37-yr study period from 1979 to 2016 when changes in perennial plant communities were assessed in the Newberry Mountains, Mojave Desert, Nevada, USA. The Palmer Drought Severity Index is for the southern Nevada region. Positive values of this index signify wet conditions, while negative values indicate drought. Values below -2 , representing moderate to severe drought, are shown in the orange band. Temperature data, available for 1914 through 2016, are from the Searchlight, Nevada, weather station, $17 \mathrm{~km}$ northwest of our study area and at an elevation of $1,079 \mathrm{~m}$.

based on relative density exceeded $50 \%$ for all community types and was high $(>67 \%)$ between 2008 and 2016 (Fig. 5).

All three compositional turnover measures (number of species gained, lost, or persisting) varied temporally (Table 3). Between 1979 and 2016, an average of 40\% (mid-elevation Larrea community) to $46 \%$ (both the low-elevation Encelia and high-elevation mixed communities) of species on a transect persisted (Fig. 6). Between 19\% (Encelia and mixed communities) and 30\% (Larrea community) of species were lost. Proportionally more species were gained than lost in the Encelia and mixed communities compared to the Larrea community, accounting for their overall increase in species density through time. Between 30\% (Larrea community) and $35 \%$ (Encelia and mixed communities) of species, on average, were colonizers of transects and therefore gained between 1979 and 2016.

\section{Biotic homogenization (Hypothesis 2)}

There was mixed evidence for biotic homogenization. Species evenness and diversity increased between 1979 and later years, the opposite of homogenization (Table 4). Similarity of species composition among transects within community types changed little through time, maintaining within-community heterogeneity. The only evidence for biotic homogenization was that between-community similarity increased by $14 \%$ between 1979 and 2008, but this trend reversed between 2008 and 2016 as communities diversified.

\section{Species-elevation relationships (Hypothesis 3)}

There was inconsistent support for the hypothesis that species distributions would shift upward. The mean maximum, minimum, average, and range of elevations species inhabited did not change significantly through time (Fig. 7). In terms of the proportion of species, twice as many species increased as decreased their maximum elevational limit. However, the proportion of species shifting in minimum and average elevation did not change significantly, nor did the elevational ranges that species inhabited.

Correlating 1979 and 2016 elevations that species inhabited identified that the rise in the number of species 
TABLE 3. Response variables and statistical results for perennial vegetation change during a 37-yr period in the Newberry Mountains, Mojave Desert, Nevada, USA.

\begin{tabular}{|c|c|c|c|c|c|c|c|}
\hline \multirow[b]{3}{*}{ Variable } & \multicolumn{3}{|c|}{$F$} & \multicolumn{4}{|c|}{ Pseudo- $F$} \\
\hline & \multirow[b]{2}{*}{ Year $(Y)$} & \multirow[b]{2}{*}{ Community $(\mathrm{C})$} & \multirow[b]{2}{*}{$\mathrm{Y} \times \mathrm{C}$} & \multirow[b]{2}{*}{ Year } & \multicolumn{3}{|c|}{ Within-community year comparisons } \\
\hline & & & & & $\mathrm{E}$ & $\mathrm{L}$ & M \\
\hline \multicolumn{8}{|l|}{ Abundance } \\
\hline Species density & $18.0(<0.001)$ & $54.3(<0.001)$ & $5.4(<0.001)$ & & & & \\
\hline Plant density & $6.1(0.003)$ & $16.2(<0.001)$ & $1.8(0.137)$ & & & & \\
\hline Plant cover & $36.2(<0.001)$ & $15.2(<0.001)$ & $1.0(0.389)$ & & & & \\
\hline \multicolumn{8}{|l|}{ Sørensen similarity } \\
\hline Relative density & & & & $5.7(<0.001)$ & $3.0(<0.001)$ & $3.2(<0.001)$ & $5.7(<0.001)$ \\
\hline Relative cover & & & & $4.3(<0.001)$ & $2.5(0.011)$ & $3.2(0.001)$ & $3.1(<0.001)$ \\
\hline Frequency & & & & $11.5(<0.001)$ & $3.9(<0.001)$ & $8.7(<0.001)$ & $7.3(<0.001)$ \\
\hline \multicolumn{8}{|l|}{ Jaccard similarity } \\
\hline Presence/absence & & & & $5.7(<0.001)$ & $1.7(0.005)$ & $3.0(<0.001)$ & $4.4(<0.001)$ \\
\hline \multicolumn{8}{|c|}{ Compositional turnover } \\
\hline Persistent & & & & $64.7(<0.001)$ & $11.7(<0.001)$ & $18.5(<0.001)$ & $44.1(<0.001)$ \\
\hline Gained & & & & $37.7(<0.001)$ & $3.6(0.044)$ & $13.6(<0.001)$ & $24.5(<0.001)$ \\
\hline Lost & & & & $14.7(<0.001)$ & $0.5(0.640)$ & $8.7(<0.001)$ & $6.1(0.003)$ \\
\hline
\end{tabular}

Notes: Abundance variables were analyzed using repeated-measures analysis of variance, with the following degrees of freedom: year 2, 194; community type 2, 97; and Y $\times$ C 4, 194. Similarity and turnover variables were analyzed using permutational analysis of variance for year comparisons as a main effect (degrees of freedom 2,198). Among-year comparisons were made within communities (E, Encelia community; L, Larrea; and M, mixed community). $P$ values are in parentheses.

increasing their maximum elevation limit was mostly related to species restricted to low elevations in 1979 that moved upslope by 2016 (Appendix S1: Fig. S1a). The lower limits that low-elevation species inhabited in 1979 frequently shifted upslope by 2016, while the lower limits of species already at high elevations in 1979 often shifted downslope (Appendix S1: Fig. S1b). Collectively, these changes indicated that species at low elevations in 1979 often moved their entire ranges upslope (both the lower and upper limits). Species already inhabiting high elevations in 1979 persisted at those high elevations while expanding downslope (decreasing the lower limit and expanding the elevation range inhabited).

\section{Change at the highest elevations (Hypothesis 4)}

Support was minimal for the hypothesis that the highest elevations would change the most (Fig. 8). Species density was consistently moderately correlated $\left(r^{2}=0.26-0.27\right)$ with elevation within each year, but the change in species density from one year to the next was minimally related to elevation $\left(r^{2}=0.00-0.08\right)$. Changes in other measures between 1979 and 2016 had even weaker relationships with elevation: $r^{2}$ was 0.00 for plant density and cover and $0.00-0.03$ for the proportion of species gained or lost.

\section{Environmental refugia (Hypothesis 5)}

There was minimal support for the environmental refugia hypothesis that moist sites would receive species in a warming and drying climate (Table 5). For example, multiple regression models estimating the proportion of species persisting, gained, or lost between 1979 and 2016 using environmental variables accounted for $<9 \%$ of the variance. Models estimating raw numbers of species persisting, gained, or lost accounted for more variance (13$45 \%$ ), but soil available water capacity was negatively, rather than positively, related to the number of persistent and gained species. Of 46 species gained on at least three transects and lost on at least three transects, only 9 $(20 \%)$ exhibited differences in means of environmental variables between transects on which the species were gained or lost. Furthermore, most of the nine species displayed gains on dry sites (low soil available water capacity and high insolation) and losses on moister sites, opposite the prediction that species distributions would shift to moister sites.

\section{Species traits and distributional changes (Hypothesis 6)}

Species distributional changes showed minimal relationship with indices of drought tolerance, association with disturbance, or with biogeographical range limits. Associations were minimal to non-existent $\left(r^{2}<0.02\right)$ between the drought and disturbance indices and species changes from 1979 to 2016 in maximum, minimum, average, and ranges of elevations inhabited. Species near their biogeographical range limits exhibited distributional changes similar to other species. For example, $57 \%$ of range-limit species increased their average elevational distribution between 1979 and 2016, compared to $58 \%$ of other species, with these proportions not differing $(G$ statistic $=0.1, P=0.82)$. Similarly, $50 \%$ of 13 species near their range limit and present in both 1979 and 2016 increased in their maximum elevation 


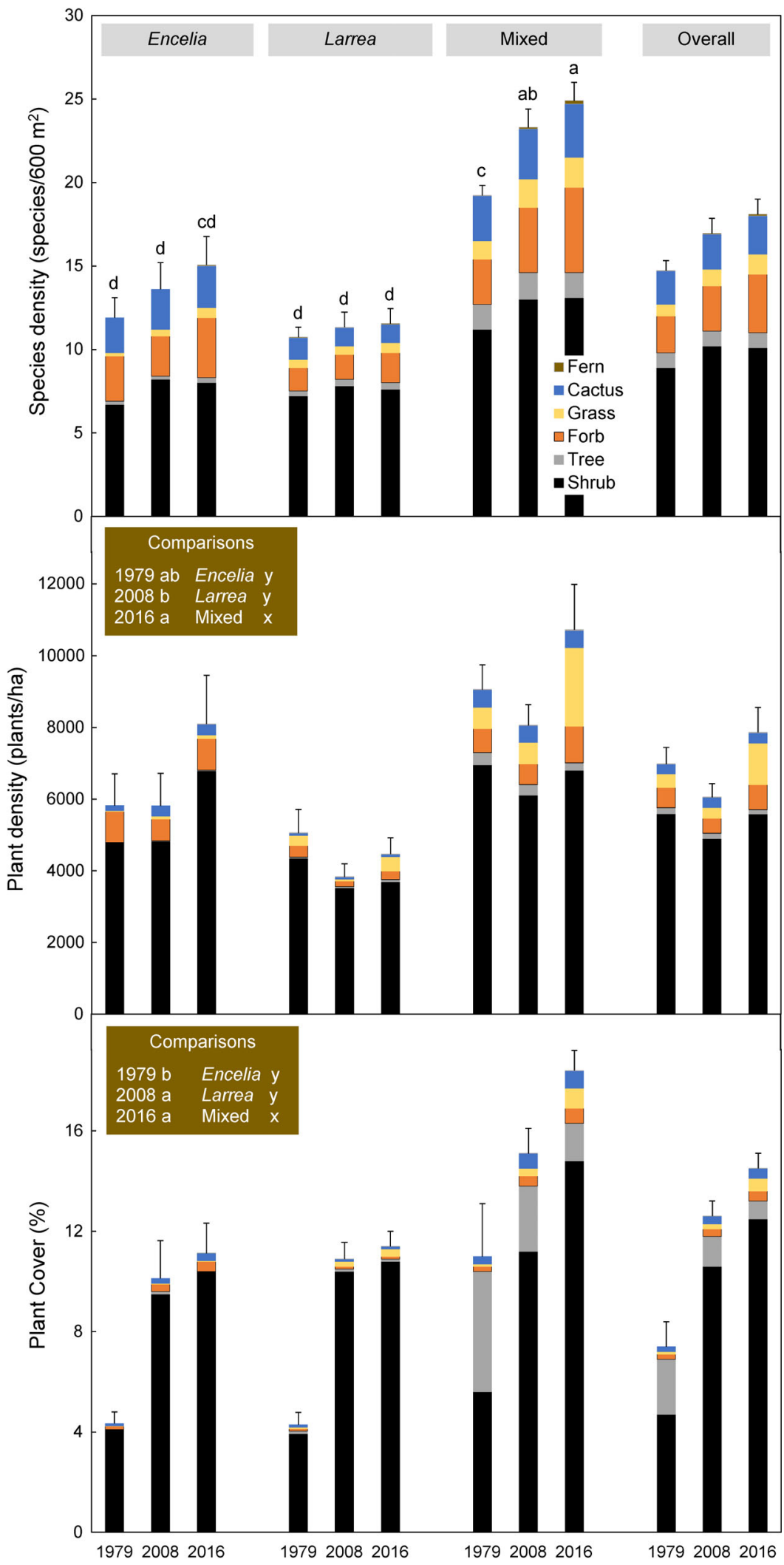

FIG. 4. Perennial species density, plant density, and cover among community types during a $37-y r$ period in the Newberry Mountains, Mojave Desert, Nevada, USA. Values are means and error bars are one standard error of means for total mean species 


\section{FIG. 4. (Continued)}

density, plant density, or cover within community-year categories. Means without shared letters differ at $P<0.05$, with multiple comparisons shown at the appropriate level of interaction or main effect based on a two-factor repeated measures analysis of variance.

distribution, compared to $49 \%$ of 74 other species present in both 1979 and 2016. Similar percentages (36\% vs. $42 \%$ ) of range-limit and other species also moved downslope below their 1979 lower-elevation limits by 2016.
Turnover did, however, vary among species (Fig. 9). Some species, such as Coleogyne ramosissima, Junperus californica, Larrea tridentata, Eriogonum fasciculatum, and Quercus turbinella, persisted between 1979 and 2008

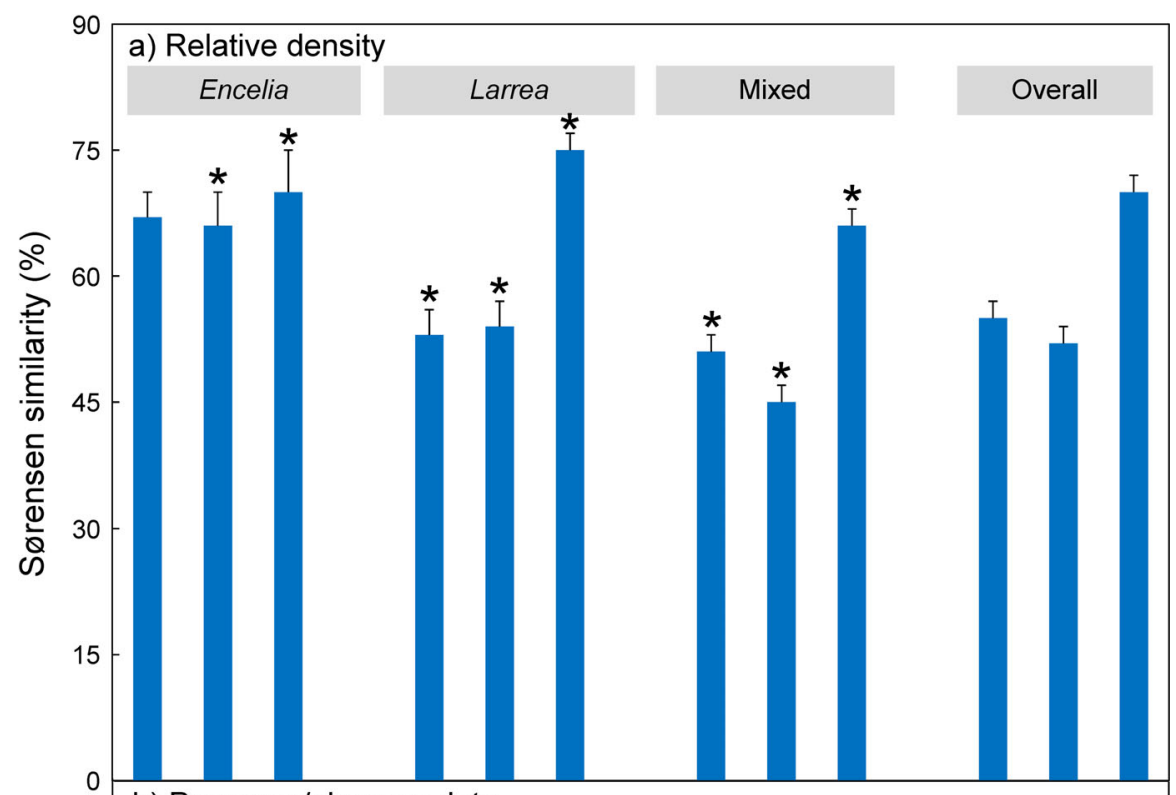

b) Presence/absence data

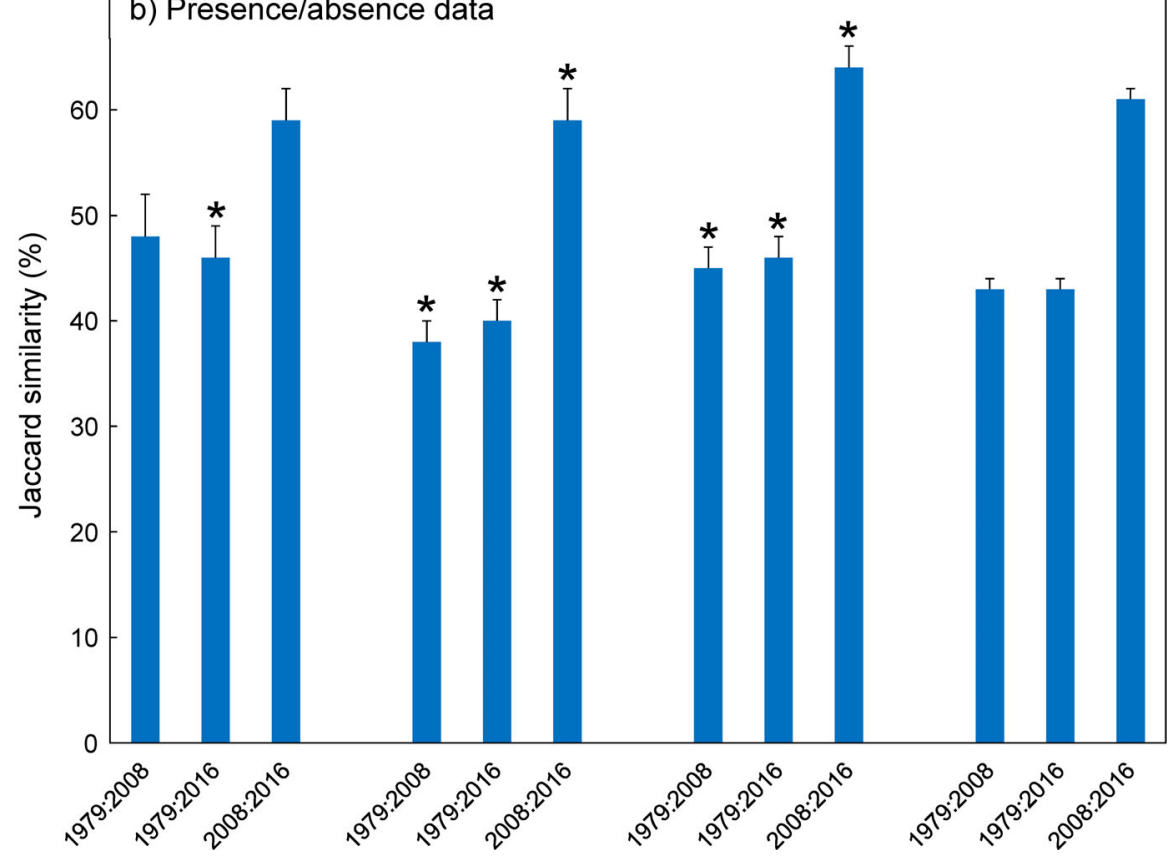

FIG. 5. Similarity of perennial plant species composition between measurement years based on (a) relative plant density and (b) presence/absence data among community types during a 37-yr period in the Newberry Mountains, Mojave Desert, Nevada, USA. Values are means and error bars are one standard error of means. Asterisks note pairwise comparisons of species composition between years significant at Bonferroni-corrected $P<0.05$ in permutational multivariate analysis of variance. 
a) Encelia
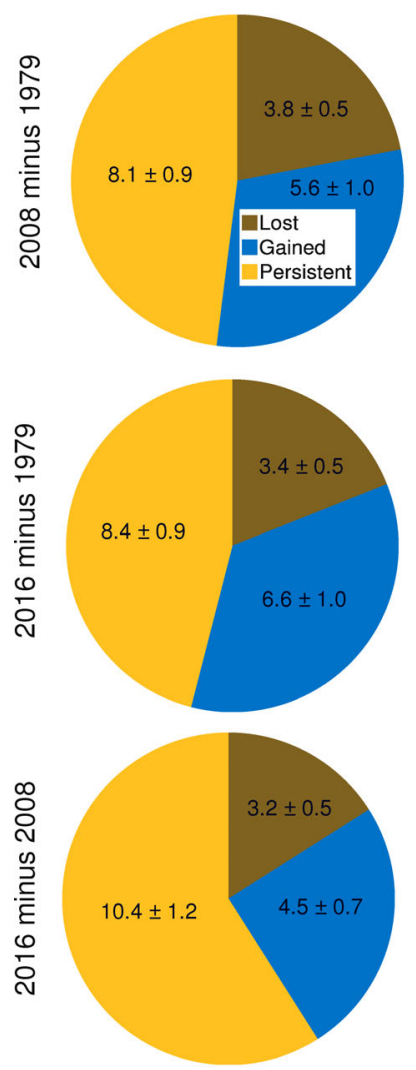

b) Larrea
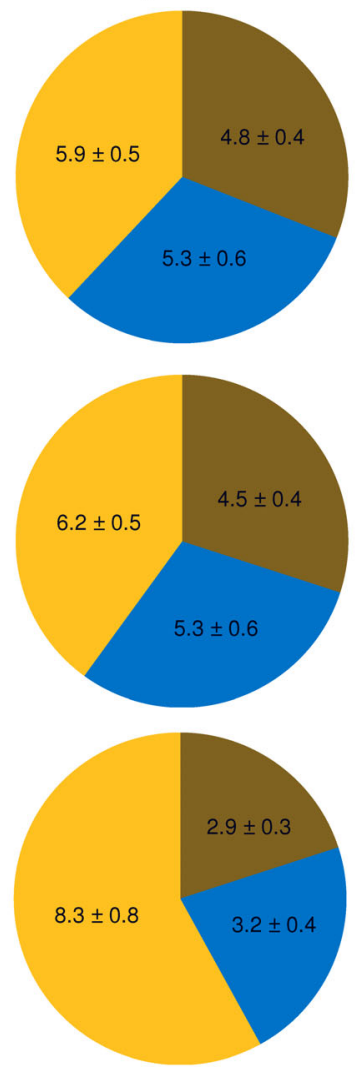

c) Mixed
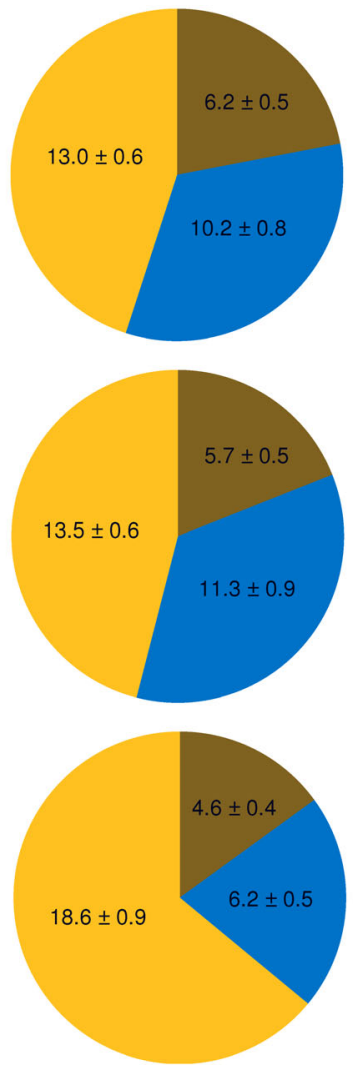

Vol. 0, No. 0

d) Overall
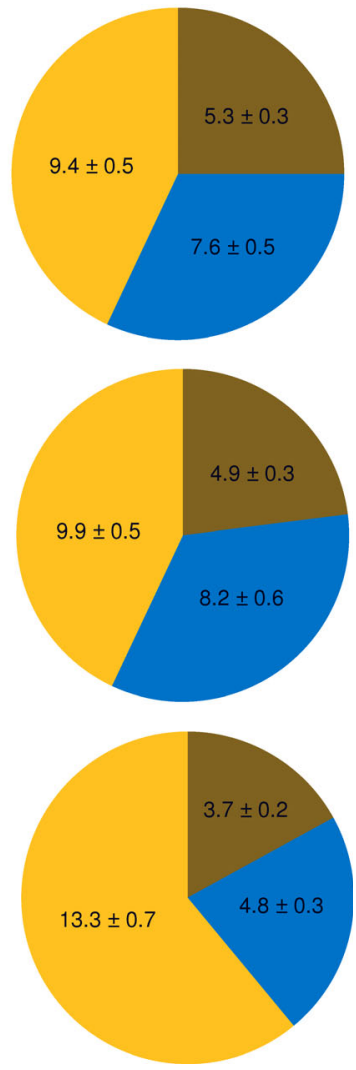

FIG. 6. Turnover in perennial plant species expressed as the proportion of species per $600-\mathrm{m}^{2}$ transect that was lost, gained, or persisted between years during a $37-y r$ period for three community types in the Newberry Mountains, Mojave Desert, Nevada, USA. Inset values in the charts are mean numbers of species $( \pm \mathrm{SE})$.

on over $80 \%$ of transects they occupied and further displayed high persistence between 2008 and 2016. Other species, such as Mammillaria tetrancistra and Mirabilis laevis, primarily colonized new transects while vacating few. A set of intermediate species, typified by Thamnosma montana and Hymenoclea salsola, persisted on, colonized, and vacated nearly equal numbers of transects. The top 10 most stable species were shrubs or trees, but otherwise little relationship was evident between turnover and growth form.

\section{DisCUSSION}

Four of six hypotheses were rejected, with the remaining two (biotic homogenization and elevational shifts) having mixed evidence (Table 1). Perennial vegetation displayed three main temporal responses: substantial, consistent change (e.g., species density $/ 600 \mathrm{~m}^{2}$ and cover); minimal change (e.g., nonnative species, limited shifts to environmental refugia); and seemingly opposing change (e.g., species moving upslope and downslope). Results suggest that (1) the 37-yr study period was favorable for native plants based on substantial increases in species diversity and cover and lack of increase in nonnative perennials; (2) there were similarities and differences in vegetation changes during the warming and drying climate with those reported from other desert sites and temperate biomes; and (3) stable and unstable species in terms of turnover occurred within a community and seemingly behaved so differently as to resemble two separate assemblages on the same site.

\section{Increases in native species}

Most native plant abundance measures, such as cover and species density, increased over time, and none decreased. Seemingly paradoxically, these increases coincided with a warming and drying climate. Possible causes for the native plant increases include recovery from livestock and feral animal grazing (which was reduced and eliminated after 1994 in the study area), shifts in precipitation timing, fewer freezes, and interactions among these factors. Native grasses are among the most favored perennial species by livestock including feral burros in southwestern drylands and have increased under protection from grazing (Blydenstein et al. 1957, Abella 2008). Native perennial grasses in our study had low cover $(<1 \%)$, but their cover steadily increased over time to be five times greater in 2016 than in 1979. For example, 
TABle 4. Biotic homogenization in perennial vegetation during a 37-yr period in the Newberry Mountains, Mojave Desert, Nevada, USA.

\begin{tabular}{|c|c|c|c|c|c|c|}
\hline \multirow[b]{2}{*}{ Comparison } & \multirow[b]{2}{*}{1979} & \multirow[b]{2}{*}{2008} & \multirow[b]{2}{*}{2016} & \multicolumn{3}{|c|}{ Analysis of variance } \\
\hline & & & & $\mathrm{df}$ & $F$ & $P$ \\
\hline \multicolumn{7}{|l|}{ Diversity measure } \\
\hline Evenness & $0.66^{\mathrm{b}} \pm 0.01$ & $0.71^{\mathrm{a}} \pm 0.01$ & $0.69^{\mathrm{a}} \pm 0.01$ & 2,194 & 7.1 & 0.001 \\
\hline Shannon diversity & $1.44^{\mathrm{b}} \pm 0.05$ & $1.61^{\mathrm{a}} \pm 0.05$ & $1.63^{\mathrm{a}} \pm 0.06$ & 2,194 & 13.1 & $<0.001$ \\
\hline \multicolumn{7}{|l|}{ Sørensen similarity (\%) } \\
\hline \multicolumn{7}{|l|}{ Within community } \\
\hline Encelia & $56 \pm 2$ & $48 \pm 2$ & $49 \pm 2$ & & & \\
\hline Larrea & $41 \pm 1$ & $41 \pm 1$ & $45 \pm 1$ & & & \\
\hline Mixed & $23 \pm 1$ & $27 \pm 1$ & $28 \pm 1$ & & & \\
\hline Overall & $40 \pm 10$ & $39 \pm 6$ & $41 \pm 6$ & 2,4 & 0.2 & 0.812 \\
\hline \multicolumn{7}{|l|}{ Between community } \\
\hline Encelia-Larrea & 38 & 52 & 41 & & & \\
\hline Encelia-Mixed & 13 & 27 & 24 & & & \\
\hline Larrea-Mixed & 20 & 35 & 34 & & & \\
\hline Overall & $24 \pm 7$ & $38 \pm 7$ & $33 \pm 5$ & 2,4 & 15.7 & 0.025 \\
\hline
\end{tabular}

Notes: Values are mean \pm SE for diversity and within-community similarity measures. Means for the diversity measures were calculated using plant cover. Means for Sørensen within-community similarity were calculated from all pairwise comparisons between transects and overall as the average of the three community types based on $n=3$ within a year. For between-community comparisons, similarity was calculated as the similarity in species composition between community types with species composition averaged across all transects within a community and year (hence no standard errors of means). The overall between-community comparison is the average $( \pm \mathrm{SE})$ of the three community comparisons based on $n=3$ within a year. A repeated-measures analysis of variance (df, degrees of freedom) compares means among years for diversity measures and overall within-community similarity, with means without shared letters differing at $P<0.05$. Overall between-community similarity was compared among years using permutational analysis of variance, with the pseudo- $F$ statistic and $P$ value provided via randomization. No pairwise comparisons between years were significant $(P>0.05)$.

Dasyochloa pulchella was absent in 1979 and increased to inhabit $12 \%$ of transects in 2008 and $28 \%$ in 2016. This species exhibited major increases under protection from grazing in previous studies in the Sonoran (Blydenstein et al. 1957), Chihuahuan (Wondzell and Ludwig 1995), and Mojave deserts (Hereford et al. 2006). While the increase we observed in this and other grass species is consistent with recovery from grazing, it is difficult to separate potential influences of grazing and climate. As a warm-season grass, increases in summer precipitation would be anticipated as favorable for Dasyochloa. After the 1979 inventory, 1982-1984 had the most MayAugust precipitation ( $16 \mathrm{~cm} / \mathrm{yr}$, or $2.6 \times$ average $)$ of any three-year period during the 1914-2016 record, but the $32 \mathrm{yr}$ since have averaged only $4.5 \mathrm{~cm} / \mathrm{yr}(75 \%$ of average) of May-August precipitation (Searchlight, Nevada station; Western Regional Climate Center, Reno, Nevada, USA). Native desert perennial grasses generally seem more sensitive to droughts than do long-lived shrubs such as Larrea tridentata (Schultz and Ostler 1995, Munson et al. 2012). These observations suggest that recent precipitation trends would not be favorable for perennial grasses, yet they increased. McAuliffe (2016) noted the difficulty in forecasting changes in perennial grass abundance because shifts in the seasonality and amount of precipitation per rainfall event (influencing infiltration), which have been inconsistent and difficult to predict, could be more important than changes in total precipitation.
Responses of other plant groups could also be consistent with recovery from grazing. For example, two forbs showing among the largest temporal increases, Mirabilis laevis and Lotus rigidus, are favored forage species (Jennings and Berry 2015). Shrubs generally are less preferred forage than forbs and perennial grasses, but among shrubs, Krameria grayi and Ambrosia dumosa can be utilized by large herbivores (Blydenstein et al. 1957, Webb and Stielstra 1979, Bowers 1997, Abella 2008). Both of these species increased in cover after 1979 in our study. However, other shrubs, typified by Larrea tridentata, also increased and are not preferred forage (Webb and Stielstra 1979). Changes could be mediated through "nurse plant" effects, where perennial plants provide favorable environments below their canopies for the recruitment of other plants. McAuliffe (1988), for instance, found that $67-90 \%$ of juvenile Larrea occurred below existing perennials even though most of the landscape was open ground. Given the importance of nurse plants to the recruitment of Larrea and other species, increased total cover of perennials and the resulting increase in potential nurse plants could increase favored and non-favored forage species alike.

The reduced frequency of freezing temperatures since 1979 could have acted synergistically with other factors to stimulate native plant increases, especially for species groups such as cacti sensitive to freezes (Weiss and Overpeck 2005). Ferocactus cylindraceus, for example, increased in our study and also increased in the Grand 


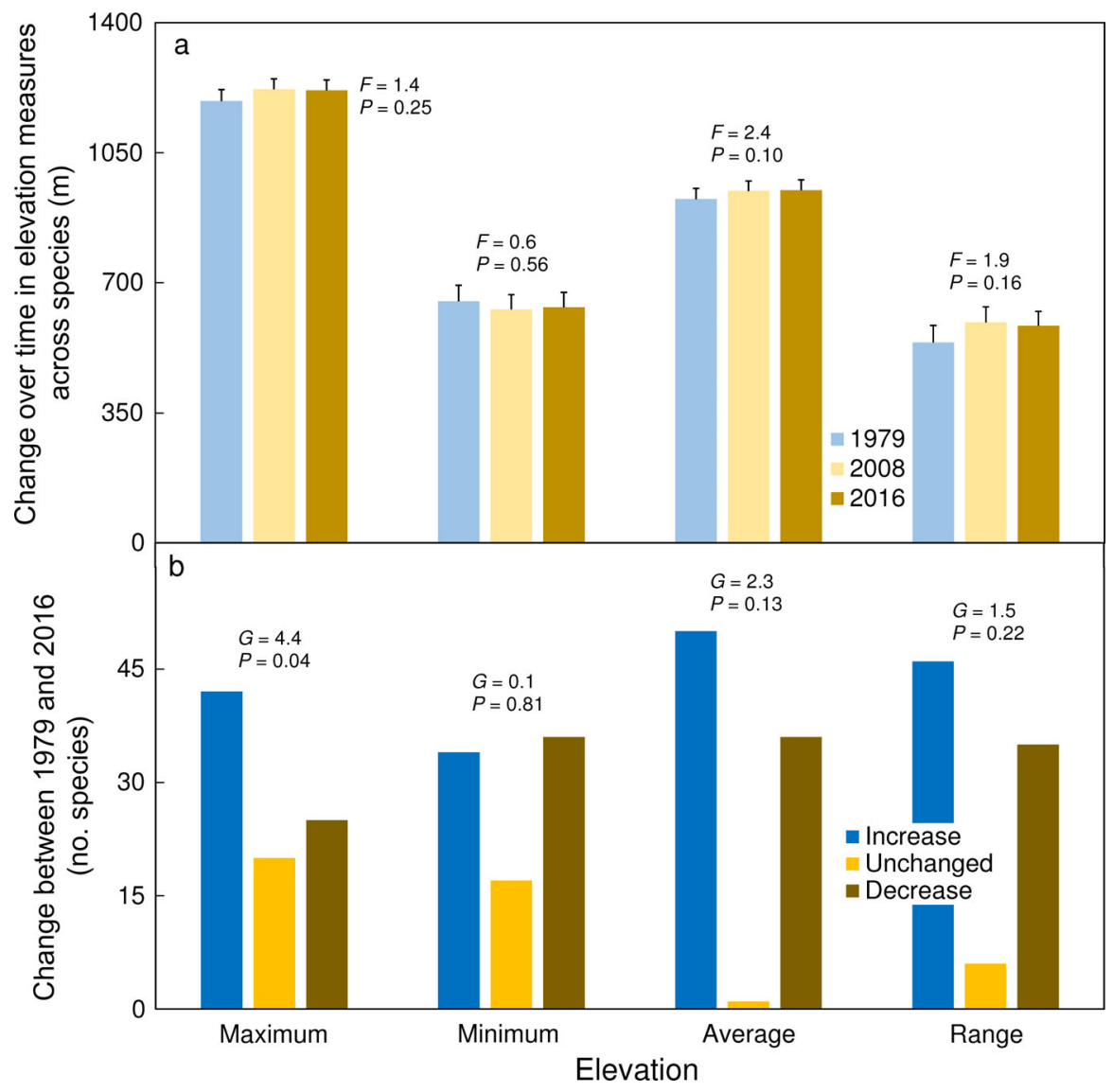

FIG. 7. Change in the maximum, minimum, average, and range (maximum minus minimum) of elevations that species inhabited over time during a 37-yr period in the Newberry Mountains, Mojave Desert, Nevada, USA. Statistics portray (a) repeated-measures analysis of variance (degrees of freedom 2,172) across years for each measure and (b) $G$ tests of goodness of fit for the proportion of species increasing or decreasing for each measure. In panel a, error bars are standard errors of means.

Canyon between 1889 and 1992 (Webb and Bowers 1993). The increase in the Grand Canyon was correlated with reduced frequency of freezes following the end of the Little Ice Age. However, substantial increases in Ferocactus occurred mainly in areas protected from feral burro grazing, as grazing was thought to have reduced nurse plants such as Ambrosia dumosa important for Ferocactus recruitment (Bowers 1997). In our study, the cover of Ambrosia increased between 1979 and 2016, concurrent with the increase in Ferocactus density. Many of the new Ferocactus evident in 2008 were between 20 and $50 \mathrm{~cm}$ tall. Growth models have estimated that a 35cm-tall Ferocactus averages 26 yr old in arid sections of the Colorado Plateau and Sonoran Desert (Bowers 1997). If growth rates in our study were similar, many of the Ferocactus would have recruited in the early 1980s. The early 1980s included record high 1982-1984 summer rainfall, which could have triggered summer germination of Ferocactus (Jordan and Nobel 1981), and began a 25yr period when below-freezing January temperatures were absent (Fig. 3).

Growth structure and physiology could account for observed differences in temporal changes among cactus species. Ferocactus cylindraceus can tolerate tissue temperatures up to a remarkable $68^{\circ} \mathrm{C}$, leading Smith et al. (1984) to conclude that its distribution was not greatly limited by high-temperature stress. A trade-off accompanying high-temperature tolerance was being more limited by cold temperatures (Nobel 1984), now less frequent. With small-diameter stems that may store less water and with lower tissue heat tolerance, Cylindropuntia spp. apparently have lower tolerance to warming and drying conditions than many other cactus growth forms (Smith et al. 1984, Bobich et al. 2014). This could relate to why Cylindropuntia were less able to exploit the recent relatively frost-free climate.

\section{Biotic homogenization}

Apparent limited manifestation of homogenizing factors could account for the minimal evidence for biotic homogenization. While nonnative species invasions are not a prerequisite for biotic homogenization, some studies have found that homogenization was correlated with increasing dominance of nonnatives ( $\mathrm{Li}$ and Waller 2015), which did not occur in our study. The lack of 

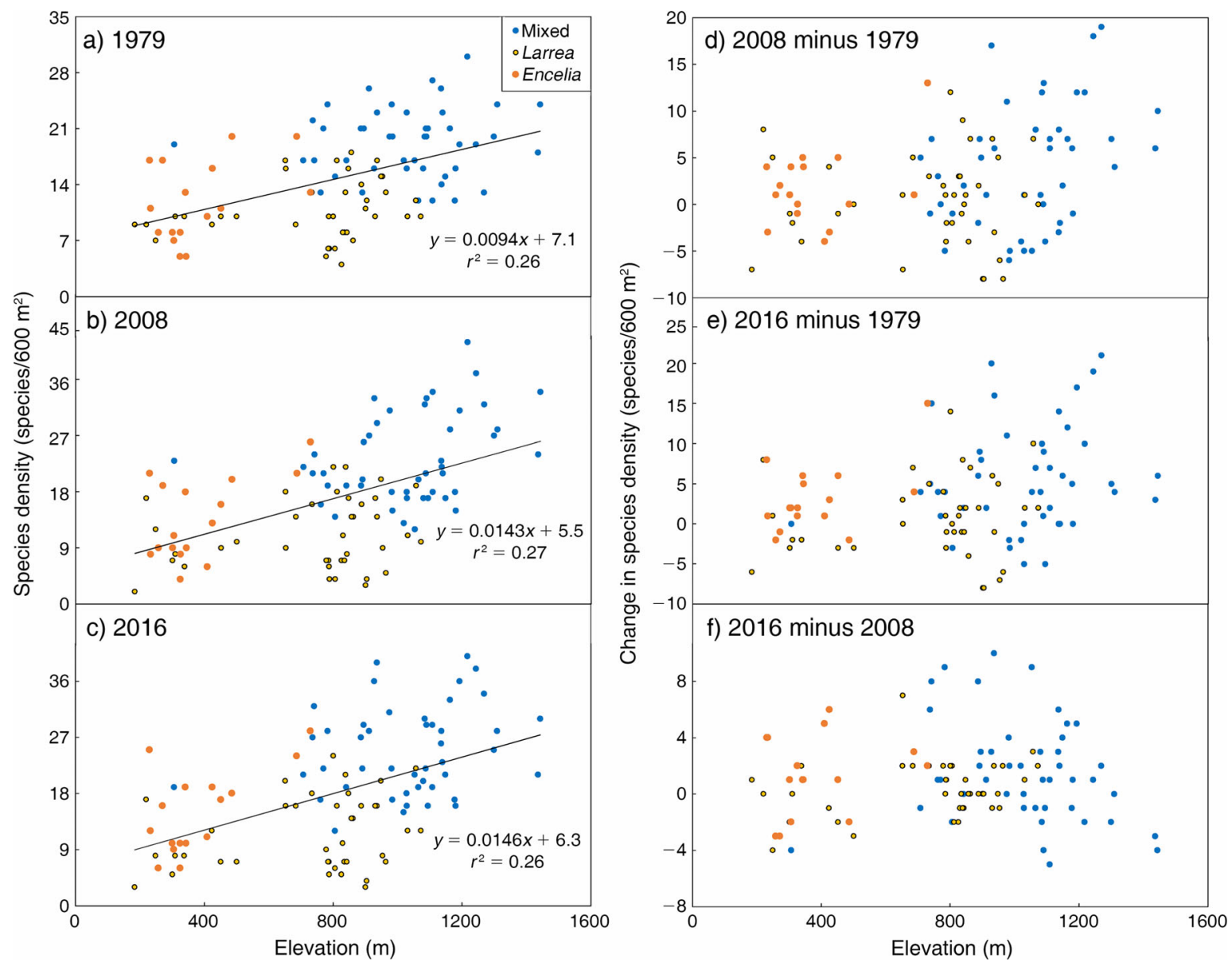

FIG. 8. Relationship between elevation and the species density and change in species density of perennial plant communities through time during a 37-yr period in the Newberry Mountains, Mojave Desert, Nevada, USA. Individual transects $(n=100)$ are symbolized according to community type.

increase in nonnative perennial species over several decades contrasts with numerous studies in temperate (e.g., Kraszewski and Waller 2008, Li and Waller 2015) and desert regions (e.g., Clarke et al. 2005, Morris et al. 2013) as well as theoretical expectations that global atmospheric change will stimulate nonnative plants (Walther et al. 2009, Diez et al. 2012, Sorte et al. 2013). Our results were also inconsistent with the idea that nonnative plant invasion is accelerating at the highest elevations (Pauchard et al. 2009). Nonnative annuals, more extensively distributed across the Mojave Desert than nonnative perennials (Abella et al. 2015b), were not prevalent in the study area either based on a previous investigation (Abella et al. 2012). It is unclear why the study area is relatively free of nonnative plants, as the Colorado River on the eastern border and highways on the western and southern borders could serve as dispersal vectors, along with a main dirt road through the study area. On the other hand, the study area's granitic soils are not among the region's most susceptible to invasion (Abella et al. 2012), the high elevations remain isolated with few human impacts, and the National Park
Service performs treatments for nonnative plants around the study area (Abella et al. 2009).

Many studies have reported relationships between nutrient enrichment (e.g., atmospheric $\mathrm{N}$ deposition) and biotic homogenization (e.g., Heinrichs and Schmidt 2017). While data on $\mathrm{N}$ deposition rates in our study were not available, the study area is $>250 \mathrm{~km}$ downwind from the nearest major urban area to the west. In the southwestern Mojave Desert in Joshua Tree National Park, Allen et al. (2009) reported that N deposition declined by an order of magnitude to minimal levels within $100 \mathrm{~km}$ downwind of southern California source areas. Experimental $\mathrm{N}$ additions along a gradient of sites varying in atmospheric $\mathrm{N}$ deposition in the Mojave Desert have produced a range of responses (increase, decrease, no change) in native species diversity, apparently linked with how abundant nonnative plants were at the time of $\mathrm{N}$ additions (Brooks 2003, Allen et al. 2009). Given the distance our study area was from upwind urban areas and the low abundance of nonnative plants, $\mathrm{N}$ enrichment should have limited importance in our study. 
TABLE 5. Assessing the environmental refugia hypothesis for vegetation change between 1979 and 2016 for species turnover in the Newberry Mountains, Mojave Desert, Nevada, USA.

\begin{tabular}{ll}
\hline \hline Variables & \multicolumn{1}{c}{ Metrics } \\
\hline Community & $x 1+x 2+$ intercept (partial $\left.r^{2}\right)$ \\
Persistent species & $-0.058 \mathrm{AWC}+0.006 \mathrm{Elev}+7.5(0.30,0.15)$ \\
Gained species & $-1.809 \mathrm{SunDurSS}+0.007 \mathrm{Elev}-0.027 \mathrm{AWC}+27.7(0.25,0.13,0.03)$ \\
Lost species & $0.003 \mathrm{Elev}-0.395 \mathrm{SunDurWS}+6.0(0.10,0.03)$ \\
Proportion persistent & $0.028 \mathrm{SunDurSS}-0.001 \mathrm{AWC}+0.1(0.03,0.02)$ \\
Proportion gained & $-0.041 \mathrm{SunDurSS}+0.9(0.08)$ \\
Proportion lost & $0.001 \mathrm{AWC}+0.2(0.09)$ \\
Species & mean $\pm \mathrm{SE}(t$ statistic, $P$ value $)$ \\
Encelia virginensis & AWC $27 \pm 9$ when gained, $76 \pm 22$ when lost $(-2.5,0.023)$ \\
Hymenoclea salsola & SunIntWS $1,482 \pm 39$ when gained, $1,205 \pm 65$ when lost $(3.6,0.002)$ \\
Larrea tridentata & Elev $549 \pm 98$ when gained, $1,031 \pm 48$ when lost $(-2.7,0.022)$ \\
Lotus rigidus & SunIntSS $6,050 \pm 106$ when gained, $6,301 \pm 49$ when lost $(-2.2,0.047)$ \\
Porophyllum gracile & Elev $965 \pm 36$ when gained, $593 \pm 122$ when lost $(3.4,0.001)$ \\
Senegalia greggii & SunDurWS $8.8 \pm 0.2$ when gained, $7.7 \pm 0.3$ when lost $(3.1,0.005)$ \\
& AWC $43 \pm 9$ when gained, $19 \pm 4$ when lost $(2.6,0.019)$ \\
Sphaeralcea ambigua & Elev $992 \pm 75$ when gained, $776 \pm 57$ when lost $(2.3,0.034)$ \\
Stephanomeria pauciflora & SunIntWS $1,474 \pm 56$ when gained, $1,245 \pm 61$ when lost $(2.8,0.009)$ \\
Xylorhiza tortifolia & AWC $27 \pm 9$ when gained, $62 \pm 11$ when lost $(-2.4,0.023)$
\end{tabular}

Notes: Abbreviations for environmental variables: AWC, soil available water capacity (mm); Elev, elevation (m); SunDurSS, sunlight duration summer solstice (h/d); SunDurWS, sunlight duration winter solstice (h/d); SunIntSS, sunlight intensity summer solstice $\left(\mathrm{Wh} \cdot \mathrm{m}^{-2} \cdot \mathrm{d}^{-1}\right)$; and SunIntWS, sunlight intensity winter solstice $\left(\mathrm{Wh} \cdot \mathrm{m}^{-2} \cdot \mathrm{d}^{-1}\right)$. The equations for community variables are multiple regressions estimating the number or proportion of species persisting, gained, or lost among 100 transects between 1979 and 2016 as a function of environmental variables. There were 46 species that were gained on at least three transects and lost on at least three transects. Only the nine species that exhibited significant differences in means of environmental variables between transects on which the species were gained or lost are shown in the table. The means are averages of environmental variables for transects where species were either gained or lost between 1979 and 2016 (compared using $t$ tests separately for each species).

The increase in species diversity that we observed after livestock grazing stopped would be consistent with recovery under some models of grazing effects in global ecosystems. For example, one model holds that species diversity increases with reduced grazing pressure in lowresource environments with a short-history of grazing (Cingolani et al. 2005), which characterizes the Mojave Desert. Under this scenario, removal of grazing would increase diversity rather than decrease it, opposite the prediction for more productive biomes with a long history of grazing. Changes in other land uses (e.g., fragmentation) or disturbance (e.g., fire), which can increase or decrease homogenization, have been minimal in our study area since 1979. Collectively, these observations suggest that many of the factors identified in other studies as associated with biotic homogenization were limited in our study.

\section{Environmental refugia}

Community changes and species shifts were minimally related to topographic and soil variables, offering little support for the environmental refugia hypothesis. While we derived environmental variables remotely and did not measure microclimates in the field, Leempoel et al. (2015) found that solar radiation and other variables derived from digital elevation models, similar to in our analysis, were correlated with field-measured microclimates. Additionally, the same variables that we used were correlated with static vegetation distribution in deserts (e.g., Parker 1988). Species fluctuations during our study suggested that as many species colonized dry as wet sites. An uncertain but potentially important factor is cold air drainage, where topographically protected or low-elevation sites at certain times experience temperatures colder than open or higher elevation sites. Sites that collect supplemental moisture (e.g., topographic depressions) often accumulate cold air (Dobrowski 2011). As a result, owing to the frost sensitivity of many desert plants, moist sites may not be good refugia. Indeed, based on Beatley (1974) in the northern Mojave Desert, a few degree increase in contemporary macroclimate would not allow Larrea tridentata to colonize moist, cold-air drainages where the species was absent. Perhaps just as importantly, the refugia hypothesis predicts species movements in a changing climate assuming that a species does not already inhabit the refugia. Packrat midden analyses in our study area suggested that two of the high-elevation taxa (Pinus monophylla and Quercus spp.) have inhabited the high elevations and moist refugia for over 19,000 yr (Leskinen 1975).

\section{Lack of relationships with disturbance and drought tolerance}

Plant species associated with disturbance have been predicted to be most responsive to climate change owing to traits typically conferring high reproductive capacity, 

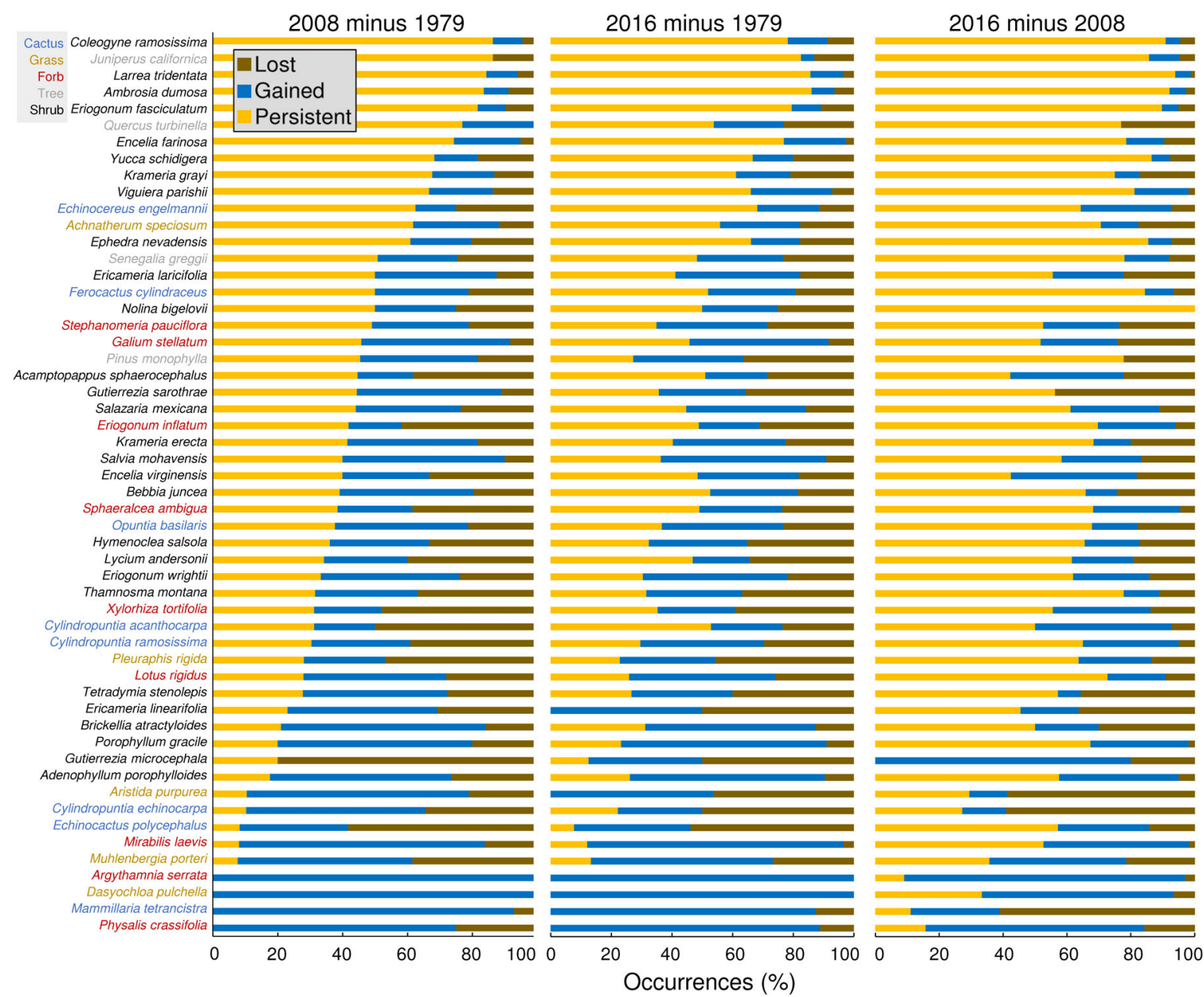

FIG. 9. Turnover in individual perennial species expressed as the percentage of $600-\mathrm{m}^{2}$ transects $(n=100)$ in which a species was lost, gained, or persisted between years during a 37-yr period in the Newberry Mountains, Mojave Desert, Nevada, USA. The figure shows 54 species that inhabited $\geq 10$ transects in at least one year (out of 159 total species).

ability for dispersal, and capability for colonizing open or vacated habitats (MacLean and Beissinger 2017). However, we did not find a close association between species associated with disturbance and turnover or elevational range shifts. This minimal association could be because species capable of colonizing disturbances were also often persistent components of the study area's mature communities. This is not uncommon in deserts, which are characterized by naturally open vegetation, contrasting with temperate grasslands or forests where canopy closure excludes early colonizers (Laughlin et al. 2011, Bodin et al. 2013). Moreover, while disturbanceassociated species do not have the longest-lived individuals in southwestern deserts, individuals of these species can still live nearly a century (Goldberg and Turner 1986, Bowers et al. 1995). As a result, disturbance-associated species can persist in undisturbed sites through long life spans of individuals and recruitment in open vegetation (Bowers et al. 1995). While our study was not designed to track individual plants, we qualitatively observed both persistence mechanisms (Fig. 2). Another reason for lack of relationships between the disturbance index and temporal change could be nurse plant effects, crucial to the recruitment of many species (Bowers 1997). Lack of available nurse plants likely limits recruitment of nurse-dependent species on disturbed sites with sparse vegetation, but nurse availability may not limit species movements in response to climate change on undisturbed sites with existing perennial cover. Indeed, we found that a quintessential nurse-dependent species not associated with disturbance, Larrea tridentata, moved at rates similar to many disturbance-associated species not requiring nurses.

Given the warming and drying climate, drought tolerance would seem important in species changes but was unrelated overall. There could be several reasons for this. If species relatively intolerant of droughts declined, they could have quickly recruited new individuals to result in no net change in persistence on transects or colonized other transects. This would follow the "pulse 
recruitment" model, which was consistent with vegetation dynamics through dry-wet cycles in several studies (e.g., Goldberg and Turner 1986, Anderson and Inouye 2001, Miriti et al. 2007). Another possibility is that despite the drying trend, it was not the primary factor in vegetation dynamics. The fact that plant cover and species density increased as the climate dried after 1979 would seem to support that supposition.

\section{Synthesis of vegetation increases and favorable conditions in southwestern drylands}

Studies of perennial vegetation change spanning at least decades after the late 1800 s in southwestern hot deserts have revealed that native plant populations have generally increased. Plant cover fluctuated through time within studies, but as in our study, increased overall (Goldberg and Turner 1986, Wondzell and Ludwig 1995, Funicelli et al. 2001, Hereford et al. 2006, Pierson et al. 2013), with few exceptions (Turner 1990). Some species have increased consistently among studies. For example, our findings support previous reports of increases in Ferocactus cylindraceus and Opuntia spp. (Goldberg and Turner 1986, Bowers et al. 1995, Bagchi et al. 2012, Pierson et al. 2013), Encelia farinosa (Turner 1990, Bowers et al. 1995, Funicelli et al. 2001), and Porophyllum gracile (Shreve and Hinckley 1937, Funicelli et al. 2001). These species are sensitive to freezing. Bowers (1994), for instance, found that Encelia germinated in the cool season as long as temperatures were above freezing for at least nine days after triggering rains. Porophyllum is near its northern limit in our study area, where warming temperatures may have alleviated the impediment of cold intolerance (Johnson 1969).

The overall increase in native plant abundance has coincided with a period generally characterized by protection from livestock grazing, rising atmospheric $\mathrm{CO}_{2}$ concentration, warming temperatures, and multi-year extremes of precipitation. While the potential importance of these factors or their interaction in changing desert communities remains poorly understood, it seems clear that the overall set of growing conditions during the last several decades in many protected areas of hot deserts has been favorable for many perennial species.

\section{Model of long-term vegetation change}

Two opposing views of desert perennial communities have been presented in the literature: that communities are relatively static and recalcitrant to change vs. that communities are dynamic with rapid turnover in species composition (Shreve 1929, Webb et al. 1987, Turner 1990, Cody 2000, Kitchen et al. 2015). Our results suggest that both perspectives have merit. There were two main components of the perennial community that behaved uniquely: persistent species with high stability and low turnover among sites, and transient species with unstable populations and high turnover among sites. In general at the extremes, the most persistent species have capacities for long life spans (>100 yr, e.g., Larrea tridentata, Coleogyne ramosissima), whereas the transient species have shorter potential life spans ( $<100 \mathrm{yr}$, e.g., Porophyllum gracile; Vasek 1980, Goldberg and Turner 1986, Bowers et al. 1995). Some transient species were entirely absent some years and abundant other years, such as Argythamnia serrata, absent in 1979 and expanding to inhabit $32 \%$ of transects in 2016. Others, such as Sphaeralcea ambigua, occurred all years but had high turnover among sites. We suggest that the desert perennial community can be conceived within a core-transient species framework (Coyle et al. 2013), reflecting the two unique assemblages of persistent and transient species within a site.

\section{Congruence with global patterns of shifts along elevational gradients}

Our results of long-term shifts in plant species distributions across elevations, among the first for a desert biome, are within the range reported for biomes globally. We found that species moved an average of $6 \mathrm{~m} /$ decade upslope in elevation. This compares with a global range of 5-30 m/decade of average upward shifts for plants in long-term studies, such as in Europe of $5 \mathrm{~m}$ in Norway mountains, $24 \mathrm{~m}$ in the Italian Alps, and $29 \mathrm{~m} /$ decade across western European forests (Lenoir et al. 2008, Parolo and Rossi 2008, Felde et al. 2012); and in the United States of $15 \mathrm{~m}$ in Hawaiian mountains, $22 \mathrm{~m}$ in California mountains, and $30 \mathrm{~m} /$ decade in Rocky Mountain forests (Kelly and Goulden 2008, Bretfeld et al. 2016, Koide et al. 2017).

But opposing the upward shifts, many studies globally have unexpectedly found that $10-33 \%$ of species have moved downslope (Parmesan and Yohe 2003, Lenoir et al. 2008, 2010, Chen et al. 2011). The percentage of species moving downslope during our study was unusually high: $41 \%$ of species shifted downward in average elevation, $41 \%$ decreased their minimum elevation limit, and $29 \%$ lowered their maximum elevation limit. In forested mountains in southwestern deserts, downslope movements of tree species were linked with anthropogenic suppression of natural fires and past logging that created openings, enabling mesic-affinity, fire-intolerant, species to move down in elevation (Cocke et al. 2005, Abella et al. 2015a). Factors in downward species movements in our study could include expanding lowerelevation limits through recovery from livestock grazing perhaps most prevalent in flatter lowlands, alteration of cold air drainage patterns in lower areas, and greater chance of dispersal and establishment in lower areas because of their greater area. Considering the expectation that deserts are among the biomes most responsive to global change (Tielbörger and Salguero-Gómez 2014), we did find that species movements were prevalent. However, distributions of many long-lived shrub 
species resisted change, and a high proportion of all species moved their ranges downslope, the opposite of what may be expected during climatic warming and drying.

\section{AcKNowledgments}

J. S. Holland established the study in 1979 as part of a master's degree completed in 1982 in the Department of Biological Sciences at the University of Nevada Las Vegas (UNLV); C. L. Roberts performed the 2008 remeasurement as part of a master's degree completed in 2012 in the Department of Environmental Studies (DES) at UNLV, with R. J. Guida's work on the 2008 remeasurement also partly fulfilling a master's degree completed in 2011 in the UNLV DES; and C. M. Norman's 2016 remeasurement was supported by the National Park Service (NPS; Lake Mead National Recreation Area) as part of official U.S. Government job duties. For support and assistance with the 1979 measurement, we thank W. Niles, C. Douglas, K. Hunter, G. Bradley, B. Fiero, C. Soong, G. Austin, M. Kurzius, K. Moor, J. Clark, W. Brock, D. Schramm, and K. Holland; for the 2008 and 2016 measurements, we thank W. J. Smith, W. Niles, J. Deacon, S. D. Smith, J. LaValley, A. Newton, T. Zaugg, and P. Riley. We also thank S. Altman (UNLV) for formatting Fig. 1; and S. D. Smith (UNLV) and three anonymous reviewers for helpful comments on the manuscript. The study was supported financially by the NPS and in-kind support from Natural Resource Conservation LLC.

\section{Literature Cited}

Abella, S. R. 2008. A systematic review of wild burro grazing effects on Mojave Desert vegetation, USA. Environmental Management 41:809-819.

Abella, S. R. 2010. Disturbance and plant succession in the Mojave and Sonoran Deserts of the American Southwest. International Journal of Environmental Research and Public Health 7:1248-1284.

Abella, S. R., J. E. Spencer, J. Hoines, and C. Nazarchyk. 2009. Assessing an exotic plant surveying program in the Mojave Desert, Clark County, Nevada, USA. Environmental Monitoring and Assessment 151:221-230.

Abella, S. R., T. M. Embrey, S. M. Schmid, and K. A. Prengaman. 2012. Biophysical correlates with the distribution of the invasive annual red brome (Bromus rubens) on a Mojave Desert landscape. Invasive Plant Science and Management 5:47-56.

Abella, S. R., L. P. Chiquoine, and P. A. Sinanian. 2015a. Forest change over 155 years along biophysical gradients of forest composition, environment, and anthropogenic disturbance. Forest Ecology and Management 348:196-207.

Abella, S. R., N. A. Fisichelli, S. M. Schmid, T. M. Embrey, D. L. Hughson, and J. Cipra. 2015b. Status and management of non-native plant invasion in three of the largest national parks in the United States. Nature Conservation 10:71-94.

Allen, E. B., L. E. Rao, R. J. Steers, A. Bytnerowicz, and M. E. Fenn. 2009. Impacts of atmospheric nitrogen deposition on vegetation and soils at Joshua Tree National Park. Pages 78100 in R. H. Webb, L. F. Fenstermaker, J. S. Heaton, D. L. Hughson, E. V. McDonald, and D. M. Miller, editors. The Mojave Desert: ecosystem processes and sustainability. University of Nevada Press, Reno, Nevada, USA.

Anderson, M. J. 2001. A new method for non-parametric multivariate analysis of variance. Austral Ecology 26:32-46.

Anderson, J. E., and R. S. Inouye. 2001. Landscape-scale changes in plant abundance and biodiversity of a sagebrush steppe over 45 years. Ecological Monographs 71:531-556.
Ash, J. D., T. J. Givnish, and D. M. Waller. 2017. Tracking lags in historical plant species' shifts in relation to regional climate change. Global Change Biology 23:1305-1315.

Asner, G. P., A. J. Elmore, L. P. Olander, R. E. Martin, and A. T. Harris. 2004. Grazing systems, ecosystem responses, and global change. Annual Review of Environment and Resources 29:261-299.

Bagchi, S., D. D. Briske, X. B. Wu, M. P. McClaran, B. T. Bestelmeyer, and M. E. Fernández-Giménez. 2012. Empirical assessment of state-and-transition models with a long-term vegetation record from the Sonoran Desert. Ecological Applications 22:400-411.

Beatley, J. C. 1974. Effects of rainfall and temperature on the distribution and behavior of Larrea tridentata (creosote-bush) in the Mojave Desert of Nevada. Ecology 55:245-261.

Bertrand, R., J. Lenoir, C. Piedallu, G. Riofrío-Dillon, P. de Ruffray, C. Vidal, J. Pierrat, and J. Gégout. 2011. Changes in plant community composition lag behind climate warming in lowland forests. Nature 479:517-520.

Blydenstein, J., C. R. Hungerford, G. I. Day, and R. R. Humphrey. 1957. Effect of domestic livestock exclusion on vegetation in the Sonoran Desert. Ecology 38:522-526.

Bobich, E. G., N. L. Wallace, and K. L. Sartori. 2014. Cholla mortality and extreme drought in the Sonoran Desert. Madroño 61:126-136.

Bodin, J., V. Badeau, E. Bruno, C. Cluzeau, J. Moisselin, G. Walther, and J. Dupouey. 2013. Shifts of forest species along an elevational gradient in Southeast France: climate change or stand maturation? Journal of Vegetation Science 24:269 283.

Bowers, J. E. 1994. Natural conditions for seedling emergence of three woody species in the northern Sonoran Desert. Madroño 41:73-84.

Bowers, J. E. 1997. Demographic patterns of Ferocactus cylindraceus in relation to substrate age and grazing history. Plant Ecology 133:37-48.

Bowers, J. E., R. H. Webb, and R. J. Rondeau. 1995. Longevity, recruitment and mortality of desert plants in Grand Canyon, Arizona, USA. Journal of Vegetation Science 6:551-564.

Bretfeld, M., S. B. Franklin, and R. K. Peet. 2016. A multiplescale assessment of long-term aspen persistence and elevational range shifts in the Colorado Front Range. Ecological Monographs 86:244-260.

Brooks, M. L. 2003. Effects of increased soil nitrogen on the dominance of alien annual plants in the Mojave Desert. Journal of Applied Ecology 40:344-353.

Bureau of Land Management. 1982. Clark County grazing environmental impact statement. Bureau of Land Management, Las Vegas, Nevada, USA.

Cahill, A. E., et al. 2013. How does climate change cause extinction? Proceedings of the Royal Society B 280:20121890.

Chen, I.-C., J. K. Hill, R. Ohlemüller, D. B. Roy, and C. D. Thomas. 2011. Rapid range shifts of species associated with high levels of climate warming. Science 333:1024-1026.

Cingolani, A. M., I. Noy-Meir, and S. Díaz. 2005. Grazing effects on rangeland diversity: a synthesis of contemporary models. Ecological Applications 15:757-773.

Clarke, P. J., P. K. Latz, and D. E. Albrecht. 2005. Long-term changes in semi-arid vegetation: invasion of a non-native perennial grass has larger effects than rainfall variability. Journal of Vegetation Science 16:237-248.

Clavel, J., R. Julliard, and V. Devictor. 2011. Worldwide decline of specialist species: toward a global functional homogenization? Frontiers in Ecology and the Environment 9:222-228.

Clavero, M., D. Villero, and L. Brotons. 2011. Climate change or land use dynamics: do we know what climate change indicators indicate? PLoS ONE 6:e18581. 
Cocke, A. E., P. Z. Fulé, and J. E. Crouse. 2005. Forest change on a steep mountain gradient after extended fire exclusion: San Francisco Peaks, Arizona, USA. Journal of Applied Ecology 42:814-823.

Cody, M. L. 2000. Slow-motion population dynamics in Mojave Desert perennial plants. Journal of Vegetation Science 11:351-358.

Coyle, J. R., A. H. Hurlbert, and E. P. White. 2013. Opposing mechanisms drive richness patterns of core and transient bird species. American Naturalist 181:E83-E90.

Daly, C., M. Halbleib, J. I. Smith, W. P. Gibson, M. K. Doggett, G. H. Taylor, J. Curtis, and P. P. Pasteris. 2008. Physiographically sensitive mapping of climatological temperature and precipitation across the conterminous United States. International Journal of Climatology 28:2031-2064.

Diez, J. M., et al. 2012. Will extreme climatic events facilitate biological invasions? Frontiers in Ecology and the Environment 10:249-257.

Dobrowski, S. Z. 2011. A climatic basis for microrefugia: the influence of terrain on climate. Global Change Biology 17:1022-1035.

Felde, V. A., J. Kapfer, and J. Grytnes. 2012. Upward shift in elevational plant species ranges in Sikkilsdalen, central Norway. Ecography 35:922-932.

Funicelli, C. S., P. J. Anning, and D. S. Turner. 2001. Long-term vegetation monitoring at Saguaro National Park: a decade of change. Technical Report No. 70. U.S. Geological Survey, Tucson, Arizona, USA.

Goldberg, D. E., and R. M. Turner. 1986. Vegetation change and plant demography in permanent plots in the Sonoran Desert. Ecology 67:695-712.

Groffman, P. M., et al. 2012. Long-term integrated studies show complex and surprising effects of climate change in the northern hardwood forest. BioScience 62:1056-1066.

Guida, R. J., S. R. Abella, W. J. Smith, H. Stephen, and C. L. Roberts. 2014. Climatic change and desert vegetation distribution: assessing thirty years of change in southern Nevada's Mojave Desert. Professional Geographer 66:311-322.

Heinrichs, S., and W. Schmidt. 2017. Biotic homogenization of herb layer composition between two contrasting beech forest communities on limestone over 50 years. Applied Vegetation Science 20:271-281.

Hereford, R., R. H. Webb, and C. I. Longpre. 2006. Precipitation history and ecosystem response to multidecadal precipitation variability in the Mojave Desert region, 1893-2001. Journal of Arid Environments 67:13-34.

HilleRisLambers, J., S. G. Yelenik, B. P. Colman, and J. M. Levine. 2010. California annual grass invaders: the drivers or passengers of change? Journal of Ecology 98:1147-1156.

Holland, J. S. 1982. A floristic and vegetation analysis of the Newberry Mountains, Clark County, Nevada. M.Sc. thesis. University of Nevada Las Vegas, Las Vegas, Nevada, USA.

Jennings, W. B., and K. H. Berry. 2015. Desert tortoises (Gopherus agassizii) are selective herbivores that track the flowering phenology of their preferred food plants. PLoS ONE 10:e0116716.

Johnson, R. R. 1969. Monograph of the plant genus Porophyllum (Compositae: Helenieae). University of Kansas Science Bulletin 48:225-267.

Jordan, P. W., and P. S. Nobel. 1981. Seedling establishment of Ferocactus acanthodes in relation to drought. Ecology 62:901-906.

Jump, A. S., C. Mátyás, and J. Peñuelas. 2009. The altitude-forlatitude disparity in the range retractions of woody species. Trends in Ecology and Evolution 24:694-701.

Kapfer, J., and J. Grytnes. 2017. Large climate change, large effect? Vegetation changes over the past century in the European high arctic. Applied Vegetation Science 20:204-214.
Kelly, A. E., and M. L. Goulden. 2008. Rapid shifts in plant distribution with recent climate change. Proceedings of the National Academy of Sciences USA 105:11823-11826.

Kimball, S., A. L. Angert, T. E. Huxman, and D. L. Venable. 2010. Contemporary climate change in the Sonoran Desert favors cold-adapted species. Global Change Biology 16:15551655.

Kitchen, S. G., S. E. Meyer, and S. L. Carlson. 2015. Mechanisms for maintenance of dominance in a nonclonal desert shrub. Ecosphere 6:252.

Koide, D., K. Yoshida, C. C. Daehler, and D. Mueller-Dombois. 2017. An upward shift of native and non-native vascular plants over 40 years on the island of Hawai'i. Journal of Vegetation Science 28:939-950.

Kraszewski, S. E., and D. M. Waller. 2008. Fifty-five year changes in species composition on dry prairie remnants in south-central Wisconsin. Journal of the Torrey Botanical Society 135:236-244.

Lato, L. J. 2006. Soil survey of Clark County area, Nevada. U.S. Department of Agriculture, Natural Resources Conservation Service, U.S. Government Printing Office, Washington, D.C., USA.

Laughlin, D. C., M. M. Moore, and P. Z. Fulé. 2011. A century of increasing pine density and associated shifts in understory plant strategies. Ecology 92:556-561.

Leach, M. K., and T. J. Givnish. 1996. Ecological determinants of species loss in remnant prairies. Science 273:1555-1558.

Leempoel, K., C. Parisod, C. Geiser, L. Daprà, P. Vittoz, and S. Joost. 2015. Very high-resolution digital elevation models: are multi-scale derived variables ecologically relevant? Methods in Ecology and Evolution 6:1373-1383.

Lenoir, J., J. C. Gégout, P. A. Marquet, P. de Ruffray, and H. Brisse. 2008. A significant upward shift in plant species optimum elevation during the 20th century. Science 320:17681771.

Lenoir, J., J. Gégout, A. Guisan, P. Vittoz, T. Wohlgemuth, N. E. Zimmerman, S. Dullinger, H. Pauli, W. Willner, and J. Svenning. 2010. Going against the flow: potential mechanisms for unexpected downslope range shifts in a warming climate. Ecography 33:295-303.

Leskinen, P. H. 1975. Occurrence of oaks in late Pleistocene vegetation in the Mojave Desert of Nevada. Madroño 23:234-235.

Li, D., and D. Waller. 2015. Drivers of observed biotic homogenization in pine barrens of central Wisconsin. Ecology 96:1030-1041.

MacLean, S. A., and S. R. Beissinger. 2017. Species' traits as predictors of range shifts under contemporary climate change: a review and meta-analysis. Global Change Biology 23:4094-4105.

McAuliffe, J. R. 1988. Markovian dynamics of simple and complex desert plant communities. American Naturalist 131:459 490.

McAuliffe, J. R. 2016. Perennial-grass dominated plant communities of the eastern Mojave Desert region. Desert Plants 32:4-90.

McCarty, J. P. 2001. Ecological consequences of recent climate change. Conservation Biology 15:320-331.

McCluney, K. E., J. Belnap, S. L. Collins, A. L. Gonzélez, E. M. Hagen, J. N. Holland, B. P. Kotler, F. T. Maestre, S. D. Smith, and B. O. Wolf. 2012. Shifting species interactions in terrestrial dryland ecosystems under altered water availability and climate change. Biological Reviews 87:563-582.

McKnight, T. L. 1958. The feral burro in the United States: distribution and problems. Journal of Wildlife Management 22:163-179. 
McLaughlin, B. C., D. D. Ackerly, P. Z. Klos, J. Natali, T. E. Dawson, and S. E. Thompson. 2017. Hydrologic refugia, plants, and climate change. Global Change Biology 23:2941-2961.

Miriti, M. N., S. Rodríguez-Buriticá, S. J. Wright, and H. F. Howe. 2007. Episodic death across species of desert shrubs. Ecology 88:32-36.

Morris, C., L. R. Morris, A. J. Leffler, C. D. Holifield Collins, A. D. Forman, M. A. Weltz, and S. G. Kitchen. 2013. Using long-term datasets to study exotic plant invasions on rangelands in the western United States. Journal of Arid Environments 95:65-74.

Munson, S. M., J. Belnap, C. D. Schelz, M. Moran, and T. W. Carolin. 2011. On the brink of change: plant responses to climate on the Colorado Plateau. Ecosphere 2:art68.

Munson, S. M., R. H. Webb, J. Belnap, J. A. Hubbard, D. E. Swann, and S. Rutman. 2012. Forecasting climate change impacts to plant community composition in the Sonoran Desert region. Global Change Biology 18:1083-1095.

National Park Service. 1994. Burro management environmental impact statement. National Park Service, Boulder City, Nevada, USA.

Newingham, B. A., C. H. Vanier, L. J. Kelly, T. N. Charlet, and S. D. Smith. 2014. Does a decade of elevated $\left[\mathrm{CO}_{2}\right]$ affect a desert perennial plant community? New Phytologist 201:498504.

Nobel, P. S. 1984. Extreme temperatures and thermal tolerances for seedlings of desert succulents. Oecologia 62:310-317.

Olden, J. D., and N. L. Poff. 2003. Toward a mechanistic understanding and prediction of biotic homogenization. American Naturalist 162:442-460.

Parker, K. C. 1988. Environmental relationships and vegetation associates of columnar cacti in the northern Sonoran Desert. Vegetatio 78:125-140.

Parmesan, C. 2006. Ecological and evolutionary responses to recent climate change. Annual Review of Ecology and Systematics 37:637-669.

Parmesan, C., and M. E. Hanley. 2015. Plants and climate change: complexities and surprises. Annals of Botany 116:849-864

Parmesan, C., and G. Yohe. 2003. A globally coherent fingerprint of climate change impacts across natural systems. Nature 421:37-42.

Parolo, G., and G. Rossi. 2008. Upward migration of vascular plants following a climate warming trend in the Alps. Basic and Applied Ecology 9:100-107.

Pauchard, A., et al. 2009. Ain't no mountain high enough: plant invasions reaching new elevations. Frontiers in Ecology and the Environment 7:479-486.

Pierson, E. A., R. M. Turner, and J. L. Betancourt. 2013. Regional demographic trends from long-term studies of saguaro (Carnegiea gigantea) across the northern Sonoran Desert. Journal of Arid Environments 88:57-69.

Puhl, L. E., S. B. Perelman, W. B. Batista, S. E. Burkhart, and R. J. C. León. 2014. Local and regional long-term diversity changes and biotic homogenization in two temperate grasslands. Journal of Vegetation Science 25:1278-1288.

Ross, L. C., S. J. Woodin, A. J. Hester, D. B. A. Thompson, and H. J. B. Birks. 2012. Biotic homogenization of upland vegetation: patterns and drivers at multiple spatial scales over five decades. Journal of Vegetation Science 23:755-770.

Schultz, B. W., and W. K. Ostler. 1995. Effects of prolonged drought on vegetation associations in the northern Mojave Desert. Pages 228-235 in B. A. Roundy, E. D. McArthur, J. S. Haley, and D. K. Mann, compilers. Proceedings: wildland shrub and arid land restoration symposium. General Technical Report INT-GTR-315. U.S. Department of Agriculture, Forest Service, Intermountain Research Station, Ogden, Utah, USA.

Shreve, F. 1929. Changes in desert vegetation. Ecology 10:364 372.

Shreve, F., and A. L. Hinckley. 1937. Thirty years of change in desert vegetation. Ecology 18:463-478.

Smith, S. D., B. Didden-Zopfy, and P. S. Nobel. 1984. High temperature responses of North American cacti. Ecology 65:643-651.

Sorte, C. J. B., et al. 2013. Poised to prosper? A cross-system comparison of climate change effects on native and nonnative species performance. Ecology Letters 16:261-270.

Tielbörger, K., and R. Salguero-Gómez. 2014. Some like it hot: are desert plants indifferent to climate change? Progress in Botany 75:377-400.

Turner, R. M. 1990. Long-term vegetation change at a fully protected Sonoran Desert site. Ecology 71:464-477.

Vasek, F. C. 1980. Creosote bush: long-lived clones in the Mojave Desert. American Journal of Botany 67:246-255.

Verstraeten, G., L. Baeten, T. Van Den Broeck, P. De Frenne, A. Demey, W. Tack, B. Muys, and K. Verheyen. 2013. Temporal changes in forest plant communities at different site types. Applied Vegetation Science 16:237-247.

Walker, B., C. Miller, L. L. Claiborne, J. Wooden, and J. Miller. 2007. Geology and geochronology of the Spirit Mountain batholith, southern Nevada: implications for timescales and physical processes of batholith construction. Journal of Volcanology and Geothermal Research 167:239-262.

Walther, G., et al. 2009. Alien species in a warmer world: risks and opportunities. Trends in Ecology and Evolution 24:686693.

Webb, R. H., and J. E. Bowers. 1993. Changes in frost frequency and desert vegetation assemblages in Grand Canyon, Arizona. Pages 71-82 in K. T. Redmond, editor. Proceedings of the Ninth Annual Pacific Climate (PACLIM) Workshop, 2124 April 1992. California Department of Water Resources, Interagency Ecological Studies Program Technical Report 34, Sacramento, California, USA.

Webb, R. H., and S. S. Stielstra. 1979. Sheep grazing effects on Mojave Desert vegetation and soils. Environmental Management 3:517-529.

Webb, R. H., J. W. Steiger, and R. M. Turner. 1987. Dynamics of Mojave Desert shrub assemblages in the Panamint Mountains, California. Ecology 68:478-490.

Weiss, J. L., and J. T. Overpeck. 2005. Is the Sonoran Desert losing its cool? Global Change Biology 11:2065-2077.

Wondzell, S., and J. A. Ludwig. 1995. Community dynamics of desert grasslands: influences of climate, landforms, and soils. Journal of Vegetation Science 6:377-390

\section{SUPPORTING INFORMATION}

